\section{1}

2

3

4 5

6

7 \section{7} . 9 0

\title{
Assessment of general condition of fish inhabiting a moderately contaminated aquatic environment
}

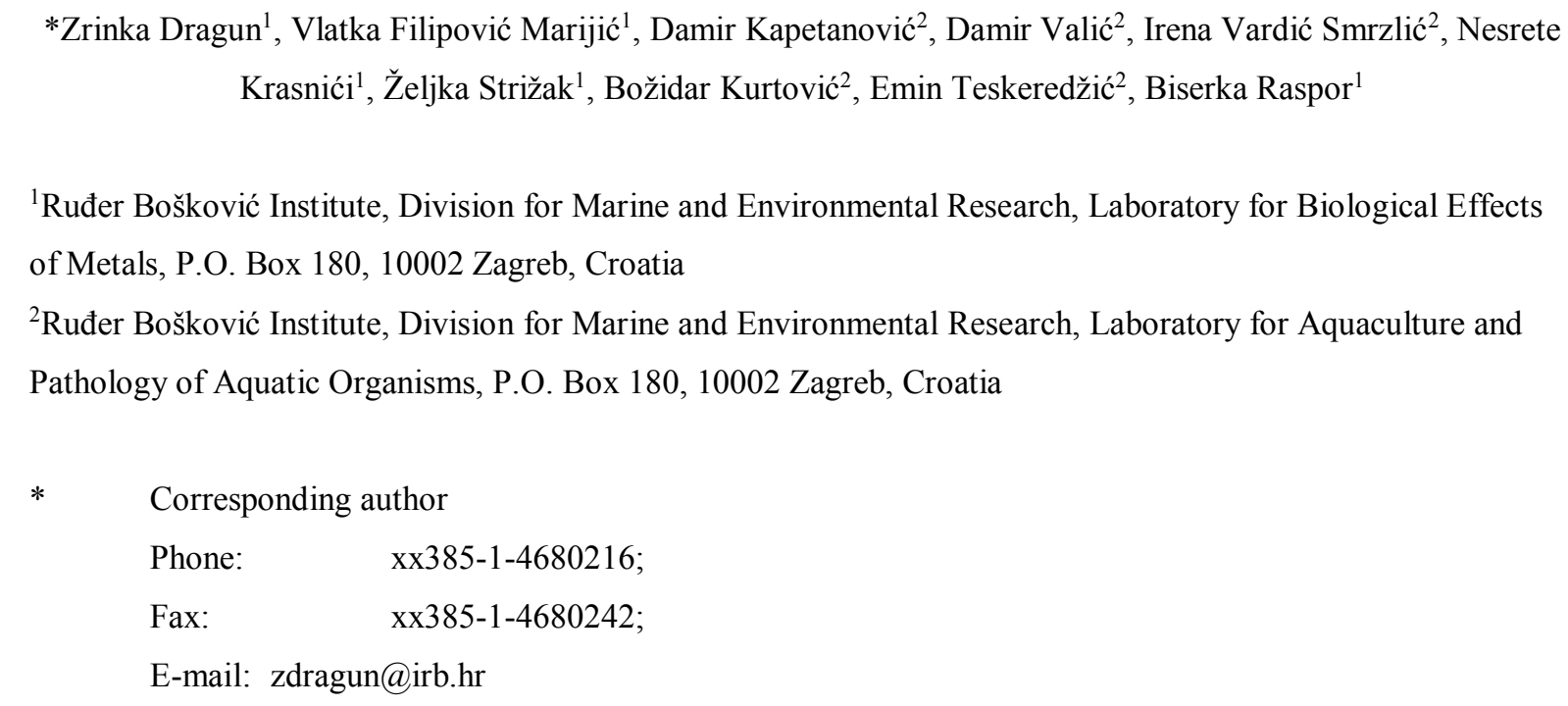

$$
\text { Phone: } \quad \text { xx385-1-4680216; }
$$$$
\text { Fax: } \quad \text { xx385-1-4680242; }
$$

E-mail: zdragun@irb.hr 
Dragun, Zrinka; Filipović Marijić, Vlatka; Kapetanović, Damir; Valić, Damir; Vardić Smrzlić, Irena; Krasnići, Nesrete; Strižak, Željka; Kurtović, Božidar; Teskeredžić, Emin; Raspor, Biserka. Assessment of general condition of fish inhabiting a moderately contaminated aquatic environment. // Environmental science and pollution research. 20 (2013), 7; 4954-4968. Abstract

The assessment of general condition of fish in the moderately contaminated aquatic environment was performed on the European chub (Squalius cephalus) caught in September 2009 in the Sutla River in Croatia. Although increases of the contaminants in this river (trace and macro elements, bacteria), as well as physico-chemical changes (decreased oxygen saturation, increased conductivity), were still within the environmentally acceptable limits, their concurrent presence in the river water possibly could have induced stress in aquatic organisms. Several biometric parameters, metallothionein (MT) and total cytosolic protein concentrations in chub liver and gills were determined as indicators of chub condition. Microbiological and parasitological analyses were performed with the aim to evaluate chub predisposition for bacterial bioconcentration and parasitic infections. At upstream river sections with decreased oxygen saturation $(\sim 50 \%)$, decreased Fulton condition indices were observed (FCI: $0.94 \mathrm{~g} \mathrm{~cm}^{-3}$ ), whereas gonadosomatic (GSI: 2.4\%), hepatosomatic (HSI: 1.31\%) and gill indices $(1.3 \%)$ were increased compared to oxygen rich downstream river sections (dissolved oxygen $\sim 90 \%$; FCI: $1.02 \mathrm{~g}$ $\mathrm{cm}^{-3}$; GSI: 0.6\%; HSI: 1.08\%; gill index: $1.0 \%$ ). Slight increase of MT concentrations in both organs at upstream (gills: $1.67 \mathrm{mg} \mathrm{g}^{-1}$; liver: $1.63 \mathrm{mg} \mathrm{g}^{-1}$ ) compared to downstream sites (gills: $1.56 \mathrm{mg} \mathrm{g}^{-1}$; liver: $1.23 \mathrm{mg}$ $\mathrm{g}^{-1}$ ), could not be explained by induction caused by increased metal levels in the river water, but presumably by physiological changes caused by general stress due to low oxygen saturation. In addition, at the sampling site characterized by inorganic and faecal contamination, increased incidence of bacterial bioconcentration in internal organs (liver, spleen, kidney) was observed, as well as decrease of intestinal parasitic infections, which is a common finding for metal contaminated waters. Based on our results, it could be concluded that even moderate contamination of river water by multiple contaminants could result in unfavourable living conditions and cause detectable stress for aquatic organisms. 
Dragun, Zrinka; Filipović Marijić, Vlatka; Kapetanović, Damir; Valić, Damir; Vardić Smrzlić, Irena; Krasnići, Nesrete; Strižak, Željka; Kurtović, Božidar; Teskeredžić, Emin; Raspor, Biserka. Assessment of general condition of fish inhabiting a moderately contaminated aquatic environment. // Environmental science and pollution research. 20 (2013), 7; 4954-4968.

\section{Introduction}

For in-depth understanding of processes occurring in aquatic ecosystems, it is necessary to simultaneously gather information on physico-chemical and microbiological characteristics of the river water, as well as on the biological indicators. In September of 2009, a comprehensive assessment of the water quality of the Sutla River in Croatia was conducted, which indicated only moderate, i. e. environmentally acceptable river water contamination, according to Croatian and European legislations and recommendations (Dragun et al. 2011). It comprised analyses of trace and macro elements, and physico-chemical and microbiological parameters (Dragun et al. 2011). Specifically, the upper flow of this river (Fig. 1, sites 1 and 2) was characterized by moderately decreased dissolved oxygen level (51.2-53.7\%) and increased presence of heterotrophic bacteria in the water (20000-24000 $\mathrm{cfu} \mathrm{mL}^{-1}$ ) compared to the lower flow of the river (Table 1), which is a probable sign of organic enrichment of the river water (Dragun et al. 2011). Within the upper river flow, a confined area (Fig. 1; site 2) was additionally burdened by faecal and inorganic contaminants, as seen from increased level of total coliforms (15739 MPN/100 mL), increased conductivity of the river water $\left(976 \mu \mathrm{S} \mathrm{cm}^{-1}\right)$, and increased levels of several dissolved trace (e.g. Pb, Rb, Tl, Cd, Li, Sb, Mn, Sn, Mo) and macro elements (e.g. Na and K) in comparison to the remaining sampling sites (Table 1). The reported concentrations of each of the trace elements individually still have not exceeded the limits considered as hazardous for the aquatic life, and both faecal and organic pollution at the majority of the sampling sites was considered as only moderate (Dragun et al. 2011). As a conclusion and in accordance with current legal requirements for good ecological status of natural waters, the Sutla River water quality was defined as satisfactory and acceptable in the monitoring report (Teskeredžić et al. 2009).

However, based on the fact that multiple disturbances occurred concurrently in the aquatic system, the aquatic organisms inhabiting the impacted section of this river were likely exposed to unfavourable conditions which could increase stress levels and result in changes of their general condition, as well as deterioration of their health status. For example, hypoxia caused by eutrophication and organic pollution is now considered to be amongst the most pressing and critical water pollution problems in the world (Pollock et al. 2007). Some authors indicate that hypoxia occurs when the level of dissolved oxygen drops below the survival levels, commonly thought to be at $2.0 \mathrm{mg} \mathrm{L}^{-1}$ or less (e.g. Chesney et al. 2000). However, hypoxia also describes the conditions where dissolved oxygen is lower than saturation levels (e.g. Hattink et al. 2005), which was the case observed in the Sutla River. In fact, researchers have often suggested that a moderate decline in dissolved oxygen from optimum levels is sufficient to substantially increase the threat to aquatic life from other contaminants (Barton and Taylor1996). Pollock et al. (2007) suggested that the interacting effects of hypoxia and chemical contamination is an area requiring investigation, especially taking into consideration the increasing trend of hypoxia occurrence in natural waters. In addition, considerable evidence indicates that exposure of fish to complex mixtures such as sewage effluent can lead to endocrine alterations (Sepúlveda et al. 2002). Exposure of fish to sublethal concentrations of contaminants may also impose considerable physiological stress, resulting in a number of manifestations such as reduced growth, impaired reproduction, predisposition to disease, reduced locomotory and predatory performance, or reduced capacity to tolerate subsequent stress (Adams et al. 1989). 
Dragun, Zrinka; Filipović Marijić, Vlatka; Kapetanović, Damir; Valić, Damir; Vardić Smrzlić, Irena; Krasnići, Nesrete; Strižak, Željka; Kurtović, Božidar; Teskeredžić, Emin; Raspor, Biserka. Assessment of general condition of fish inhabiting a moderately contaminated aquatic environment. // Environmental science and pollution research. 20 (2013), 7; 4954-4968.

Accordingly, the main aim of this study was to assess the general condition of fish from a moderately but diversely contaminated aquatic environment. European chub (Squalius cephalus L. 1758), a member of the Cyprinidae family, was chosen as a bioindicator species, because it is a common and widely distributed species throughout European waters, the Black Sea Basin, the Caspian Sea Basin and the Azov Sea Basin (Berg 1964; Şaşi 2004). In ecotoxicological studies the use of a wide battery of biological responses is recommended since single biomarkers cannot reflect the impairment of organism's health and/or the adaptation to impaired environmental conditions (Cajaraville et al. 2000). Therefore, our specific aim was to study several parameters associated with condition and health of the chub from the Sutla River, including the Fulton condition index, gonadosomatic and hepatosomatic indices. Measurements of physiological indices and reproductive biomarkers for assessing the effects of different stressors on fish are extremely valuable because they incorporate several levels of biological organization (Sepúlveda et al. 2004). The condition factor is commonly used as a simple general indicator of physical and physiological status of fish, in the sense of a relative measure of body composition, fatness, feeding, growth, reproductive stage and body energy content of fish (Elliott 1976; Pulliainen and Korhonen 1990; Encina and Granado-Lorencio 1997). Similarly, the gonadosomatic index has been used as an indicator of the composition stage, development and energy content of the gonads (Mills and Eloranta 1985; Encina and Granado-Lorencio 1997). Hepatosomatic index, on the other hand, was confirmed as a useful biomarker of aquatic pollution (van Dyk et al. 2012). We have also applied measurement of total cytosolic protein concentrations in liver and gills, due to the fact that proteins are a major constituent in the metabolism of animals and therefore it is important to study the changes in protein metabolism in the stress conditions, such as metal exposure. Changes of total protein concentrations that may occur are the increase due to the increased protein synthesis or decrease due to the breakdown of proteins (De Smet and Blust 2001). More specifically, we have measured metallothionein (MT) concentrations as indicator of metal exposure, but also of general stress in chub. MTs are a class of ubiquitously occurring low molecular mass cysteine- and metal-rich proteins containing sulphur-based metal clusters, which have important roles in the homeostasis of essential trace metals $(\mathrm{Zn}$ and $\mathrm{Cu})$ or sequestration of environmental toxic metals (e.g. $\mathrm{Cd}$ and $\mathrm{Hg}$ ), as well as in the protection against oxidative damage (Vašák 2005). Although MT is a known biomarker of metal exposure, and its induction presents a biochemical response to increased bioavailability of metals in the environment, it is also inducible by factors unrelated to metal contamination, such as handling, starvation, anoxia, freezing, and the presence of antibiotics, vitamins or herbicides (Amiard et al. 2006). Finally, chub predisposition for infectious health disorders was evaluated based on the microbiological and parasitological analyses.

\section{Materials and methods}

\subsection{Study area and period}

The study was carried out on the Sutla River, a 91-km-long river flowing along the Croatian and Slovenian state border, with a water discharge between 0.73 and $68.8 \mathrm{~m}^{3} \mathrm{~s}^{-1}$ and a catchment area of $581 \mathrm{~km}^{2}$ (Dragun et al. 2011). It is a tributary to the Sava River, a major river in Croatia. Five locations (Fig. 1) under different anthropogenic pressures (industrial wastewater, household and thermal bath discharges, agricultural runoff; Dragun et al., 2011) were selected for fish sampling. Several physico-chemical, microbiological and inorganic parameters, indicating moderate contamination of the water quality of the selected sampling sites are presented 
Dragun, Zrinka; Filipović Marijić, Vlatka; Kapetanović, Damir; Valić, Damir; Vardić Smrzlić, Irena; Krasnići, Nesrete; Strižak, Željka; Kurtović, Božidar; Teskeredžić, Emin; Raspor, Biserka. Assessment of general condition of fish inhabiting a moderately contaminated aquatic environment. // Environmental science and pollution research. 20 (2013), 7; 4954-4968. in the Table 1. The fish were sampled in the late summer of 2009 , from September $14^{\text {th }}$ to $16^{\text {th }}$, to avoid the influence of the spring reproductive period on the analyzed parameters, as suggested by Podrug and Raspor (2009).

\subsection{Fish sampling}

The selected fish for this study was European chub (S. cephalus L.), an omnivorous fish species, that is wide spread in European freshwaters, and therefore suitable for monitoring purposes. Fifteen chub specimens were caught per site, or 75 in total. The sampling was performed by electro fishing (Hans Grassl, EL63 II GI, 5.0 KW, Honda GX270, 300/600V max., 27/15A max.) in accordance with the Croatian standard HRN EN 14011:2005. Captured fish were kept alive in an opaque plastic tank with aerated river water until further processing in the laboratory. Individual fish were anesthetized with Clove oil (Sigma Aldrich) and sacrificed. The gills and liver were dissected and stored at $-80^{\circ} \mathrm{C}$ until further analyses.

\subsection{Determination of biometric parameters}

Several biometric parameters were recorded: total mass, total length, mass of the liver, gills, and gonads. Fulton condition indices (FCI) were calculated in accordance with Rätz and Lloret (2003), based on total chub mass and length. Organosomatic indices (hepatosomatic (HSI, \%), gonadosomatic (GSI, \%) and gill index (\%) were calculated as ratios between tissue mass (liver, gonads and gills, respectively) and total body mass (g), multiplied with 100 (Şaşi 2004). A few scales (5-10) were taken from the lateral line below the dorsal fin for subsequent age determination by counting growth annuli using an optical microscope (BH-2 Olympus; 40 times amplification; Ognev and Fink 1956; Treer et al. 1995). For sex determination, we have compared the results obtained in the laboratory through both macroscopic and microscopic examination of gonads. For microscopic identification of sex, a section of gonad tissue from each fish was placed on a glass microscope slide. The slides were viewed under a 40 and 100 times amplification using optical microscope (BH-2 Olympus).

\subsection{Isolation of cytosolic fractions from fish liver and gills}

The samples of gill and hepatic tissue were cut into small pieces, diluted 6 times with cooled homogenization buffer $\left(20 \mathrm{mM}\right.$ Tris-HCl/Base, Sigma, $\mathrm{pH} 8.6$ at $\left.4^{\circ} \mathrm{C}\right)$, supplemented with reducing agent dithiotreitol (Sigma, final concentration $2 \mathrm{mM}$ ) to prevent protein oxidation and metal redistribution among cellular constituents (Falchuk and Czupryn 1991), and then homogenized by 10 strokes of Potter-Elvehjem homogenizer (Glas-Col) in ice cooled tube at 6,000 rpm. For better separation, the homogenates were centrifuged two times in the Avanti J-E centrifuge (Beckman Coulter) at $50,000 \times \mathrm{g}$ for $2 \mathrm{~h}$ at $4^{\circ} \mathrm{C}$. Supernatant (S50) obtained after the second centrifugation, which represents water soluble cytosolic tissue fraction, was stored at $-20^{\circ} \mathrm{C}$ for metal analyses in cytosol and at $-80^{\circ} \mathrm{C}$ for total cytosolic protein (TP) and MT measurements.

\subsection{Determination of trace element concentrations}

The concentrations of three elements $(\mathrm{Zn}, \mathrm{Cu}$ and $\mathrm{Cd})$ were determined in hepatic and gill cytosols, which were 10 times diluted with Milli-Q water and acidified with $\mathrm{HNO}_{3}$ (Suprapur, Merck, final concentration in the samples $0.65 \%$ ) prior to measurements. Indium (Fluka) was added in all samples as an internal standard $(1 \mu \mathrm{g} \mathrm{L}$

\footnotetext{
${ }^{1}$ ). The measurements were performed on high resolution inductively coupled plasma mass spectrometer (HR
} 
Dragun, Zrinka; Filipović Marijić, Vlatka; Kapetanović, Damir; Valić, Damir; Vardić Smrzlić, Irena; Krasnići, Nesrete; Strižak, Željka; Kurtović, Božidar; Teskeredžić, Emin; Raspor, Biserka. Assessment of general condition of fish inhabiting a moderately contaminated aquatic environment. // Environmental science and pollution research. 20 (2013), 7; 4954-4968.

ICP-MS, Element 2, Thermo Finnigan), equipped with a double focusing mass analyzer using reverse NierJohnson geometry. An autosampler (ASX 510, Cetac Technologies) and sample introduction kit consisting of SeaSpray nebulizer and cyclonic spray chamber Twister were employed to transport the analytes into the plasma of HR ICP-MS. Measurements of ${ }^{111} \mathrm{Cd}$ were operated in low resolution mode, whereas ${ }^{63} \mathrm{Cu}$ and ${ }^{66} \mathrm{Zn}$ were measured in medium resolution mode. External calibration was performed using standards prepared in $2 \% \mathrm{HNO}_{3}$ (Suprapur, Merck) by appropriate dilutions of $100 \mathrm{mg} \mathrm{L}^{-1}$ multielement stock standard solution (Analytika). Quality control sample (QC for trace metals, UNEP GEMS/Water PE Study No. 7) was used for checking the accuracy of trace element measurements by HR ICP-MS. A generally good agreement was observed between our data and the certified values (e.g. recovery for $\mathrm{Cd}$ : $\sim 96-116 \%$; recovery for $\mathrm{Cu}: \sim 90-115 \%$ ). Limits of detection (LOD) were determined based on three standard deviations of ten consecutively determined trace element concentrations in the blank sample (2 mM Tris-HCl/Base, $0.2 \mathrm{mM}$ dithiotreitol, 0.65\% $\mathrm{HNO}_{3}$ ). $\mathrm{LODs}$ for trace elements measured within this study were as follows $\left(\mu \mathrm{g} \mathrm{L} \mathrm{L}^{-1}\right)$ : $\mathrm{Cd}-0.005, \mathrm{Cu}-0.037, \mathrm{Zn}-2.40$.

\subsection{Determination of cytosolic protein concentrations (TP)}

The concentrations of TPs were measured in the gill and hepatic cytosol (S50) according to Lowry et al. (1951). The Bio-Rad DC Protein Assay was applied according to manufacturer's instructions. The measurements were performed on the photometer Microplate Reader HT3 (Anthos, Austria) at $750 \mathrm{~nm}$ wavelength. Calibration curve was constructed with five different concentrations $\left(0.25-2.0 \mathrm{mg} \mathrm{mL}^{-1}\right)$ of bovine serum albumin (Serva, Germany) dissolved in the homogenization buffer.

\subsection{Determination of MT concentrations}

For MT determination, the cytosolic fraction (S50) was additionally heat treated to efficiently denature high molecular mass proteins which would otherwise interfere with the electrochemical MT determination (Erk et al. 2002). The cytosolic fraction was first 10 times diluted with $0.9 \% \mathrm{NaCl}$ (Suprapur, Merck), then heat-treated for $10 \mathrm{~min}$ at $85^{\circ} \mathrm{C}$ in The Dri Block (Techne), and subsequently placed on ice for $30 \mathrm{~min}$ at $4{ }^{\circ} \mathrm{C}$. The heat-treated cytosol was then centrifuged at $10,000 \mathrm{~g}$ for $15 \mathrm{~min}$ at $4{ }^{\circ} \mathrm{C}$ in Biofuge Fresco centrifuge (Kendro, USA). The resulting supernatant (HT S50) was separated from the pellet and stored at $-80^{\circ} \mathrm{C}$. MT concentrations were measured in the HT S50 by differential pulse voltammetry (DPV) following the modified Brdička procedure (Raspor et al. 2001) and using 797 VA Computrace (Metrohm, Switzerland) with a three-electrode system (hanging mercury drop electrode, $\mathrm{HMDE}$, as a working electrode, an $\mathrm{Ag} / \mathrm{AgCl} / \mathrm{saturated} \mathrm{KCl}$ reference electrode and a platinum counter electrode). The voltammetric measurements were performed in $10 \mathrm{~mL}$ of supporting electrolyte solution $\left(2 \mathrm{M} \mathrm{NH}_{4} \mathrm{Cl} / \mathrm{NH}_{4} \mathrm{OH}, 5 \mathrm{~mL}\right.$ and $\left.1.2 \times 10^{-3} \mathrm{M} \mathrm{Co}\left(\mathrm{NH}_{3}\right)_{6} \mathrm{Cl}_{3}, 5 \mathrm{~mL} ; \mathrm{pH}=9.5\right)$ thermostated at $20^{\circ} \mathrm{C}$ and deaerated with extra pure nitrogen, to which $20-40 \mu \mathrm{L}$ of chub gill or hepatic HT S50 was added. Instrumental parameters for DPV were the following: potential scan from $-0.9 \mathrm{~V}$ to $-1.65 \mathrm{~V}$; scan rate $0.005 \mathrm{~V} \mathrm{~s}$ 1; voltage pulse amplitude $0.025 \mathrm{~V}$; duration of the pulse application $0.057 \mathrm{~s}$; and a clock time $0.5 \mathrm{~s}$. MT concentrations expressed as $\mu \mathrm{g} \mathrm{mL}^{-1}$ were derived from the calibration straight line, which was constructed by using the commercially available, $>95 \%$ pure, rabbit liver zinc-MT (I+II) (MT-95-P, Ikzus Proteomics, Italy) dissolved in $0.25 \mathrm{M} \mathrm{NaCl}$. The final results expressed as $\mathrm{mg} \mathrm{MT} \mathrm{g}^{-1}$ of wet gill or hepatic tissue were obtained by multiplying MT concentrations measured in the cytosol with six, which is tissue dilution factor. 
Dragun, Zrinka; Filipović Marijić, Vlatka; Kapetanović, Damir; Valić, Damir; Vardić Smrzlić, Irena; Krasnići, Nesrete; Strižak, Željka; Kurtović, Božidar; Teskeredžić, Emin; Raspor, Biserka. Assessment of general condition of fish inhabiting a moderately contaminated aquatic environment. // Environmental science and pollution research. 20 (2013), 7; 4954-4968.

2.8. Isolation and determination of bacteria from fish organs

Frequency and intensity of bacterial bioconcentration in chub were recorded and used as indicator of the changes of the chub immunological status at the sites characterized by unfavourable conditions. Number of bacterial colonies in chub was determined for four organs: gills as an external organ in direct contact with ambient water, and three internal organs: liver, spleen and kidney. First, the gills were sampled for bacteriological analysis with sterile inoculation loop. Then, after the abdominal cavity was aseptically opened, spleen, liver and kidney were sampled for bacteriological analysis using the same technique. All the samples were placed onto Trypticase Soy agar plates (BD-BBL) for isolation and enumeration. The plates were incubated for $24-48 \mathrm{~h}$ at $22^{\circ} \mathrm{C}$. Thereafter, isolated colonies were enumerated and the results were expressed as number of Colony Forming Units per organ (CFU).

\subsection{Isolation and determination of parasites from fish intestine}

Initial parasitological investigation of endoparasites was done macroscopically, after fish dissection. Then, acanthocephalans were taken from intestine using sterile instruments and fixated in 10\%-buffered formalin or $70 \%$ ethanol. Afterwards, parasites were immersed in lactophenol and observed under binocular magnifier and optical microscope (BH-2 Olympus), or they were immersed in cedar oil and observed under microscope. Species determination has been done on the basis of morphological characteristics (Moravec 2007).

\subsection{Data processing and statistical analyses}

Statistical program SigmaPlot 11.0 for Windows was applied for graph creating and statistical analyses. Several nonparametric statistical tests were applied. Kruskal-Wallis One Way Analysis of Variance on Ranks with posthoc Dunn's test was used for the comparison of the results obtained at five sampling sites (for chub age and mass, FCI, GSI, HSI, gill index, MT, TP, Zn, Cu, Cd, intensity of bacterial bioconcentration and abundance of parasitic infections). Mann-Whitney Rank Sum Test was used for the comparison of the results obtained at upstream and downstream sampling area (for FCI, GSI, HSI, gill index, MT (in liver and gills), TP (in liver and gills), $\mathrm{Zn}$ (in gills) and $\mathrm{Cu}$ (in liver)), as well as for the comparison between males and females, two age groups, and for the comparison of MT and TP concentrations measured in two organs (gills and liver). Correlation between FCI and GSI was calculated by use of Spearman correlation coefficient. MT variability in liver/gills was analysed by multiple regression analysis on standardized values using Forward Stepwise Regression, with the following independent variables: total chub mass, HSI, gill index, FCI, GSI, TP in liver/gills, cytosolic Zn in liver/gills, cytosolic $\mathrm{Cu}$ in liver/gills and cytosolic $\mathrm{Cd}$ in liver/gills.

\section{Results and discussion}

\subsection{Fish biometric parameters} The European chub (S. cephalus) sampled for this study were 1-4 years old, with total mass in range from 33 to $400 \mathrm{~g}$. The females were predominant ( $\sim 80 \%)$, and their proportion was considerably higher compared to our previous study on the European chub from the Sava River (Dragun et al. 2009a; 59-66\%) or reports by Ünver (1998; 68\%) and Şaşi (2004; 73\%). However, female predominance was not associated with a specific section of the river since it was equally observed at oxygen poor upstream site (site 1) and oxygen rich downstream sites 
Dragun, Zrinka; Filipović Marijić, Vlatka; Kapetanović, Damir; Valić, Damir; Vardić Smrzlić, Irena; Krasnići, Nesrete; Strižak, Željka; Kurtović, Božidar; Teskeredžić, Emin; Raspor, Biserka. Assessment of general condition of fish inhabiting a moderately contaminated aquatic environment. // Environmental science and pollution research. 20 (2013), 7; 4954-4968.

(sites 3 and 5; Fig. 2a). When age and size were considered, statistically significant differences were observed between sites, with the generally smallest and youngest chub sampled at the most contaminated site 2 (Fig. 2 b,c; Table 1). It could be a random finding; however, it is also possible that due to rather unfavourable living conditions, older fish abandon this area and advance down the river flow. For example, the response of many fishes upon detecting inadequate living conditions, specifically low levels of dissolved oxygen, is to simply avoid the area. They migrate from low oxygen waters to normoxic waters (Pihl et al. 1991). Some species, like inland silverside (Menidia beryllina) will temporally avoid even the areas that fall below $4.7 \mathrm{mg} \mathrm{O}_{2} \mathrm{~L}^{-1}$ (Weltzien et al. 1999). In addition, it is interesting to notice that low dissolved oxygen levels have size dependent effects on the community structure, i.e. smaller individuals use waters of lower oxygen levels more than the larger fish (Burleson et al. 2001), which is consistent with our findings. The Sutla River water analyses conducted subsequently in October 2009 indicated that the sampling site 2, inhabited with the smallest fish, had the lowest dissolved oxygen levels continuously (3.97-6.45 $\mathrm{mg} \mathrm{L}^{-1}$ ), whereas dissolved oxygen at the other oxygen poor sampling site occasionally has reached higher values $\left(8.48 \mathrm{mg} \mathrm{L}^{-1}\right)$.

Association with oxygen saturation of river water could also be made for FCI of chub caught in the Sutla River, which gradually increased from the site 1 towards the site 5 , with statistically significant differences between two outermost sites (Fig. 3a). Chub inhabiting oxygen poor upstream sampling area had $\sim 10 \%$ lower FCI compared to chub from oxygen rich downstream sampling area (Table 2). Dissolved oxygen is a key factor affecting the growth, reproduction and survival of fishes (Friesen et al. 2012). In hypoxic conditions, energy may be diverted away from expenditures of growth, development and reproduction, resulting in significant fitness costs (Kramer 1987), which could explain FCI decrease. Furthermore, FCI might reflect metabolic impact of trace metals on fish, as reported by Giguère et al. (2004) for Perca flavescens and Filipović Marijić and Raspor (2007) for Mullus barbatus. This could be an additional explanation for the decrease of chub FCI at the metal contaminated sampling site 2 .

The opposite trend was observed for gonadosomatic indices (GSI) as confirmed by a statistically significant negative correlation between FCI and GSI $(r=-0.383, p<0.001)$. GSIs of all chub gradually decreased from the site 1 towards the site 5 (Fig. 3b), and were approximately four times higher for the chub caught in the upstream than downstream sampling area (Table 2). The separate analyses for females and males further confirmed this finding. Previous reports indicated that Iberian chub (Squalius pyrenaicus) may be included in the group of fish species that spawn at the end of spring and during summer, with quiescent period during autumn and winter, since gonad development is related to increments in the daylight period, water temperature and food supply (Encina and Granado-Lorencio 1997). Accordingly, the exact period of S. cephalus spawning depends on the climate, but mostly occurs from April to June (e.g. Berg 1964; Öztaş 1989; Şaşi 2004). For mature chub during the reproductive phase, GSI was reported to be above 3\% for females (max. $7.5 \%$ ), and above $1.5 \%$ for males (max. 2.5\%; Şaşi 2004). In our study, chub were sampled in the late summer, i.e. in the postspawning period, and GSI determined for females at two oxygen poor upstream sites was on average close to $3 \%$, whereas for males it was close to $1.5 \%$, as opposed to oxygen rich downstream area with GSI of both sexes below $0.7 \%$. Since hypoxia may specifically disrupt the conversion of testosterone to estradiol through aromatase activity, resulting in higher testosterone levels and higher testosterone/estradiol ratio (Shang 2006; Landry et al. 2007; 
Dragun, Zrinka; Filipović Marijić, Vlatka; Kapetanović, Damir; Valić, Damir; Vardić Smrzlić, Irena; Krasnići, Nesrete; Strižak, Željka; Kurtović, Božidar; Teskeredžić, Emin; Raspor, Biserka. Assessment of general condition of fish inhabiting a moderately contaminated aquatic environment. // Environmental science and pollution research. 20 (2013), 7; 4954-4968.

Friesen et al. 2012), it could also cause longer gonad development rate and consequently result in asynchronous breeding seasons between hypoxic and normoxic populations (Friesen et al. 2012). Some authors even suggest that the problem of endocrine disruption caused by hypoxia could potentially be more serious than that caused by known anthropogenic chemicals (Goldberg 1995; Diaz 2001).

The analysis of FCI and GSI dependence on sex and age, revealed that females had statistically significantly higher condition indices than males (medians for females: $1.01 \mathrm{~g} \mathrm{~cm}^{-3}$; for males: $0.94 \mathrm{~g} \mathrm{~cm}^{-3} ; p<0.05$ ), whereas older chubs had significantly higher GSIs compared to younger specimens (medians for 3-4-year old chub: $1.43 \%$; for $1-2$-year old chub: $0.69 \% ; p<0.01)$. Therefore, we have analyzed spatial variability of FCI separately for females and males, and observed that the increasing spatial trend was maintained for both sexes (Table 3). Similarly, although GSI varied depending on the chub age, the decreasing spatial trend was maintained for both younger, sexually immature, and older, sexually mature chub specimens (Table 3 ). This was an indication that both indices probably changed as a consequence of environmental conditions, and not physiological differences.

Although the physiological and biochemical mechanisms for hypoxia adaptation are numerous, diverse and widespread among fishes, populations maintained in chronic hypoxia tend to grow larger gills to maximize oxygen absorption (Timmerman and Chapman 2004; Graham 2006). For example, a number of parameters related to gill size (e.g. total gill surface area, filament length and lamellar area) have been found to be greater in Pseudocrenilabrus multicolor exposed to low dissolved oxygen compared with high dissolved oxygen conditions (Chapman et al. 2000 and 2008a,b). In our study, organosomatic indices for chub gills were significantly higher at upstream sampling area compared to downstream area, on average $25 \%$ (Table 2), and that increase was especially evident at the site 2 (Fig. 3c). It could be possibly associated with the continuously low oxygen saturation of the river water, since the dependence of gill index on chub age and sex was not observed. In addition, increase of the gill mass could be a consequence of other morphological anomalies in fish gills, such as hyperplasia of the lamellar epithelium, which could be induced by a variety of factors, such as environmental pollutants. However, different irritants may cause almost identical structural damage, which therefore rather reflect a generalized stress response than effect of single toxicant (Movahedinia et al. 2012).Hyperplasia inhibits the respiratory gas exchange by increasing diffusion distance and decreasing interlamellar distance, and therefore could have negative effect on the respiratory function of the fish (Movahedinia et al. 2012), and not only the effect on the gill mass. Increased gill area, as well as respiratory disturbances, would increase a metabolic cost (energetic cost of ventilation, gill maintenance and osmoregulation; Graham 2006), which could be in turn connected to lower chub condition at upstream sites (Table 2).

Hepatosomatic indices (HSI) were the highest at the metal contaminated sampling site 2 (median HSI 1.56\%; Fig. 3d). Significantly higher HSIs were reported for sharptooth catfish (Clarias gariepinus) from polluted aquatic environment $(1.4 \pm 0.5 \%)$ compared to HSI of the fish from the reference site $(0.6 \pm 0.3 \%)$. However, when evaluating HSI, some factors other than pollution should be considered, such as the age of the fish (van Dyk et al. 2012). As could be seen from our data, HSI of younger chub (median for 1-2-year old chub: 1.31\%) were $20 \%$ higher compared to older chub (median for 3-4-year old chub: 1.09\%), and the difference was statistically 
Dragun, Zrinka; Filipović Marijić, Vlatka; Kapetanović, Damir; Valić, Damir; Vardić Smrzlić, Irena; Krasnići, Nesrete; Strižak, Željka; Kurtović, Božidar; Teskeredžić, Emin; Raspor, Biserka. Assessment of general condition of fish inhabiting a moderately contaminated aquatic environment. // Environmental science and pollution research. 20 (2013), 7; 4954-4968.

significant $(p<0.05)$. Therefore, we have analyzed the spatial variability separately for HSI of younger and older chubs (Table 3), and observed that independent of the chub age, the highest HSIs were always obtained at the sampling site 2 which is contaminated with metals and faecal bacteria. In addition, in young chub, increased HSI was also obtained at the site 1 , similarly to GSI trend, indicating that liver of younger chub is more susceptible to harmful effects caused by deterioration of general living conditions, such as low oxygen availability. Sex dependence of HSI was also tested, and no differences were found between females and males.

\subsection{Metallothioneins (MT) and total cytosolic proteins (TP)}

In the gills of the Sutla River chub, MT levels were in the range from 0.66 to $2.35 \mathrm{mg} \mathrm{g}^{-1}$ (median: $1.60 \mathrm{mg} \mathrm{g}^{-1}$ ), whereas in the liver their level ranged from 0.80 to $3.73 \mathrm{mg} \mathrm{g}^{-1}$ (median: $1.42 \mathrm{mg} \mathrm{g}^{-1}$ ). The comparison of MT levels in these two organs revealed significant difference $(p<0.01)$, with median gill MT $\sim 10 \%$ higher compared to liver. Contrary, TP level was significantly lower $(p<0.001)$ in the gills (median: $87.1 \mathrm{mg} \mathrm{g}^{-1}$; range: $38.8-106.5$ $\mathrm{mg} \mathrm{g}^{-1}$ ) compared to liver (median: $114.8 \mathrm{mg} \mathrm{g}^{-1}$; range: $72.1-148.2 \mathrm{mg} \mathrm{g}^{-1}$ ), approximately $25 \%$. As a result, a percentage of MTs in total protein level was higher in the gills $(1.8 \pm 0.2 \%)$ than liver $(1.3 \pm 0.5 \%)$. This finding is consistent with previous reports of higher MT percentage in fish uptake organs, such as gills (S. cephalus: 1.72.7\%, Dragun et al. 2009a) and intestine (S. cephalus: 3-4\%, Filipović Marijić and Raspor 2010), compared to detoxification organ, such as liver (M. barbatus: 0.9\%, Filipović Marijić and Raspor 2006; S. cephalus: 1.3\%, Podrug and Raspor 2009). Since gill and intestinal epithelial tissues are involved in the uptake, detoxification and excretion processes (van Cleef et al. 2000), higher MT presence in those tissues is probably associated with the important function of MTs in metal uptake (Dragun et al. 2009a).

Constitutive MT levels in gills (median: $1.56 \mathrm{mg} \mathrm{g}^{-1}$; range: 1.02-2.85 $\mathrm{mg} \mathrm{g}^{-1}$; Dragun et al. 2009a) and liver (median: $1.55 \mathrm{mg} \mathrm{g}^{-1}$; range: 1.09-3.75 $\mathrm{mg} \mathrm{g}^{-1}$; Podrug and Raspor 2009) of chub from the weakly metal contaminated Sava River (Dragun et al. 2009b) were previously reported for the nonreproductive periods of 2005 and 2006. Gill and hepatic MT levels of the Sutla River chub were comparable with the reports for the Sava River. Since MT is a biomarker of metal exposure, this finding was an indication that metal exposure in the Sutla River water was still rather low.

Although hepatic and gill MT levels were not increased above constitutive ranges, they demonstrated very specific spatial distribution (Fig. 4a,b), especially hepatic MT. Higher levels were not restricted to the moderately metal contaminated site 2, but were characteristic of all oxygen poor upstream sites. Median hepatic MT was $\sim 30 \%$ and gill MT $\sim 10 \%$ higher at upstream than downstream sampling area (Table 2 ). It is in accordance with the recommendation that MT induction in fish should be considered a general stress response although it is particularly sensitive to heavy metals (Viarengo et al. 1999), since biomarkers like MTs may be affected by factors such as season, temperature, fish gender, nutritional status or size (Hylland et al. 1998; Filipović Marijić and Raspor 2006 and 2010). For example, MT has been shown to be elevated following stress and inflammation in fish (Baer and Thomas 1990; Maage et al. 1990). MT induction by many forms of chemical and physical stress is most prominent in liver, mediated in part by hormones and resembles an acute phase response (Bremner 1987; Kägi and Schäffer 1988). Spatial trend of TPs was not as clear as obtained for MTs, but they have also decreased towards the most downstream site in both liver and gills (Fig. 4c,d). Similarly, 
Dragun, Zrinka; Filipović Marijić, Vlatka; Kapetanović, Damir; Valić, Damir; Vardić Smrzlić, Irena; Krasnići, Nesrete; Strižak, Željka; Kurtović, Božidar; Teskeredžić, Emin; Raspor, Biserka. Assessment of general condition of fish inhabiting a moderately contaminated aquatic environment. // Environmental science and pollution research. 20 (2013), 7; 4954-4968. increased concentrations of plasma proteins (albumin and globulin) were previously observed in largemouth bass at sites contaminated by paper mill effluent compared to reference streams (Sepúlveda et al. 2004). However, in our study, the difference between upstream and downstream sampling area, although even significant in the case of liver, was much less obvious than observed for MTs, and amounted to only 5-10\% (Table 2).

For either MTs or TPs, differences between males and females were not observed, regardless of the studied tissue. Differences associated with age, on the other hand, were significant $(p<0.05)$, but rather small, and referred only to MTs. MT levels were $\sim 10 \%$ lower in younger than older chubs in both gills and liver. This finding was consistent with previous reports on less prominent sex and age related MT variability during the nonreproductive than reproductive periods in both gill and liver of the Sava River chub (Dragun et al. 2009a; Podrug and Raspor 2009). Similarly, no obvious indications of sex influence on the hepatic MT level were reported for red mullet (M. barbatus) sampled in the postspawning period (Benedicto et al. 2005).

The association of several other factors with MT variability were assessed by use of multiple linear regression analysis (Table 4). Total chub mass, total protein levels, as well as condition and organosomatic indices (FCI, HSI, gill index, GSI) were used to assess the changes of MTs connected to chub general condition, whereas the levels of metals known as MT inducers $(\mathrm{Zn}, \mathrm{Cu}, \mathrm{Cd})$ in liver and gills, were used to assess metal associated MT variability. Obtained models for liver and for gills (Table 4) could explain $35 \%$ and $52 \%$ of MT variability in each organ, respectively. It was interesting to notice which parameters stand out as the best predictors of MT changes. In both organs, significant positive association of TPs with MTs was observed, which could be expected, considering that MT is a minor protein fraction. Next to TPs, hepatic MT was also significantly associated with GSI, with higher MT levels measured in the chub with larger gonads. A significant correlation between hepatic MT levels and gonad indices was previously found for red mullet (M. barbatus; Zorita et al. 2008). In addition, higher MT concentrations during the reproductive cycle were observed in the liver of freshwater fish Salmo gairdneri (Olsson et al. 1987) and marine fish M. barbatus (Benedicto et al. 2005; Filipović Marijić and Raspor 2008). It was reported that MT levels began to increase in female fish at the onset of vitellogenesis, and that the levels peaked when spawning occurred (Olsson et al. 1987 and 1990). Elevated MT levels have also been observed in male fish at the time of spawning (Olsson et al. 1987 and 1990; Baer and Thomas 1990). Gill MT, on the other hand, was significantly associated with the gill size. Slight MT increase at the upstream sites, therefore, could be possibly associated with increased gill surface area, as well as increased gill diffusion in hypoxic conditions, which is a way to maintain adequate oxygen levels (Randall 1970 and 1982; Randall and Daxboeck 1984; Woo and Wu 1984; Timmerman and Chapman 2004).

Furthermore, in both organs a significant positive association of MT with a specific essential metal was observed, however, not with the same one. An important predictor of hepatic MT variability was cytosolic $\mathrm{Cu}$ concentration in the liver, whereas gill MT could be associated with cytosolic Zn concentration in the gills. Same as MTs, both hepatic $\mathrm{Cu}$ and gill $\mathrm{Zn}$ were significantly higher at upstream sampling sites (Table 2, Fig. 5b,c). More pronounced association of hepatic MT with $\mathrm{Cu}$ than $\mathrm{Zn}$ was previously observed in the studies by Hogstrand et al. (1991), Rotchell et al. (2001) and Benedicto et al. (2005). Hepatic $\mathrm{Zn}$ and gill Cu, on the other hand, were maintained within narrow concentration ranges and mainly comparable at all sites (Figure 5a,d). In 
Dragun, Zrinka; Filipović Marijić, Vlatka; Kapetanović, Damir; Valić, Damir; Vardić Smrzlić, Irena; Krasnići, Nesrete; Strižak, Željka; Kurtović, Božidar; Teskeredžić, Emin; Raspor, Biserka. Assessment of general condition of fish inhabiting a moderately contaminated aquatic environment. // Environmental science and pollution research. 20 (2013), 7; 4954-4968. addition to characteristic spatial variability, Zn cytosolic concentrations in the gills of all chub from the Sutla River $\left(14.3 \pm 4.9 \mu \mathrm{g} \mathrm{mL}^{-1}\right)$ were also much higher than previously defined levels, not only for nonreproductive autumn period $\left(6.3 \mu \mathrm{g} \mathrm{mL}^{-1}\right)$, but also above higher $\mathrm{Zn}$ levels characteristic for spring period $\left(10.3 \mu \mathrm{gL}^{-1}\right.$; Dragun et al. 2007). Such prominent increase of $\mathrm{Zn}$ level in the chub gills could not be explained by increased metal exposure, since dissolved $\mathrm{Zn}$ in the Sutla River water was low, below $5 \mu \mathrm{g} \mathrm{L}^{-1}$ (Dragun et al. 2011). The metal concentrations, especially for essential metals like $\mathrm{Zn}$, are known to increase following the increase of the metabolic activity (Andres et al. 2000). It could be hypothesized that increased fish respiration under hypoxic conditions could cause similar effect. Such finding was not obtained for the other metals. Gill Cu of the Sutla River chub (42.6 $\left.\pm 10.4 \mathrm{ng} \mathrm{mL} \mathrm{m}^{-1}\right)$ was even lower than previously defined constitutive levels in chub gills during the autumn period ( $\mathrm{Cu}: 68.4 \mathrm{ng} \mathrm{mL}^{-1}$; Dragun et al. 2007), whereas hepatic $\mathrm{Zn}$ and Cu were comparable in the chub from the Sutla (Zn: $6.61 \pm 1.59 \mu \mathrm{g} \mathrm{mL}^{-1} ; \mathrm{Cu}: 1.50 \pm 0.72 \mu \mathrm{g} \mathrm{mL}^{-1}$ ) and the Sava River (Zn: $4.96 \pm 1.50 \mu \mathrm{g} \mathrm{mL}$ 1; Cu: $1.51 \pm 0.82 \mu \mathrm{g} \mathrm{mL}^{-1}$; Podrug et al. 2009).

Cytosolic Cd was also included in the analyses, as a potent MT inducer which was significantly increased in both chub gills and liver at the specific sites (sites 3 and 4; Fig. 5e,f). However, Cd variability was not significantly associated with MT variability in either organ. Cytosolic $\mathrm{Cd}$ in gills was rather low $\left(0.68 \pm 0.36 \mathrm{ng} \mathrm{mL}^{-1}\right)$, $\mathrm{much}^{-}$ lower compared even to chub from weakly contaminated Sava River (2.9 ng mL ${ }^{-1}$; Dragun et al. 2007). Cytosolic Cd in liver (19.4 $\left.\pm 11.6 \mathrm{ng} \mathrm{mL}^{-1}\right)$ was, on the other hand, higher compared to reports for the Sava River chub ( $8 \pm 5 \mathrm{ng} \mathrm{mL}^{-1}$; Podrug et al. 2009), but obviously still have not reached the level high enough to induce additional MT synthesis.

\subsection{Bacterial bioconcentration and parasitic infections}

Bacterial bioconcentration frequency was the highest in the gills (Fig. 6a), with almost all studied fish infected (80-100\%). The spatial trend of bacterial bioconcentration intensity in gills was characterized by lower values at oxygen poor upstream sampling area (Fig. 6e). Compared to gills, lower bioconcentration frequency was observed in the internal organs, same as previously reported for rainbow trout (Oncorhynchus mykiss) by Kapetanović et al. (2005). The bacterial bioconcentration frequency in internal organs exhibited the following decreasing trend: liver $(17-80 \%)>$ spleen $(0-60 \%)>$ kidney $(0-40 \%)$ (Fig. 6b-d). Similarly, Pathak and Gopal (2005) found higher bacterial load in liver than spleen, and the lowest values in the kidney of freshwater catfish (Clarias batrachus). In addition, specific spatial distribution was observed for internal organs, especially for liver, with increased bioconcentration frequency at the sampling site 2 (Fig. 6b). This spatial trend was even more obvious in bioconcentration intensity of all internal organs. Generally the highest median numbers of bacterial colonies were recorded for the chub from the sampling site 2 (Fig. 6f-h), indicating higher susceptibility of internal organs to bacterial bioconcentration at the site affected by inorganic and faecal contamination. It is known that soft tissues in massive organs of fish living in water contaminated by municipal sewage and industrial effluent are more prone to bioconcentration of bacteria (Pathak and Gopal 2005). For example, Fattal et al. (1993) reported bioconcentration of aquatic bacteria such as coliforms, streptococci and aeromonads in gut, liver and muscles of tilapia fish grown in a sewage-contaminated pond. Such bioconcentration could finally lead to incidence of infectious diseases among the aquatic fauna (Pathak and Gopal 2005). After exposure of fish to pollutants, circulating levels of corticosteroids may increase, which could lead to immunological disruptions, 
Dragun, Zrinka; Filipović Marijić, Vlatka; Kapetanović, Damir; Valić, Damir; Vardić Smrzlić, Irena; Krasnići, Nesrete; Strižak, Željka; Kurtović, Božidar; Teskeredžić, Emin; Raspor, Biserka. Assessment of general condition of fish inhabiting a moderately contaminated aquatic environment. // Environmental science and pollution research. 20 (2013), 7; 4954-4968. such as reductions in leukocrit and in immunoglobulins (Soimasuo et al. 1995; Khan et al. 1996). Such changes can result in an increased susceptibility to pathogens, like bacteria (Sepúlveda et al. 2004).

Similar to bacterial bioconcentration in internal organs, a connection with metal contaminated site was also obvious for both frequency and abundance of parasitic infections. However, they exhibited opposite trends, with the lowest values observed at the most contaminated sampling site 2 (Fig. 7a,b). Similar observation was also made a year before, when the frequency of parasitic infections was also the lowest at the sampling site $2(0 \%)$, compared to the other sampling sites on the Sutla River (33-84\%; Vardić Smrzlić, unpublished results). In addition, in September 2009, only one species of intestinal parasites (Pomphorhynchus laevis) was detected in the chub from the Sutla River, whereas a year before, one fish was additionally coinfected with Acanthocephalus sp. (Vardić Smrzlić, unpublished results). Although certain parasites, particularly intestinal acanthocephalans of fish, can accumulate heavy metals at concentrations that are orders of magnitude higher than those in the host tissues or the environment (Sures et al., 1999), lower number of acanthocephalan parasites as well as lower biodiversity was previously observed in association with increased water pollution. For example, Gelnar et al. (1996) found lower abundance of $P$. laevis at the organically polluted site in the Morava River, a tributary of the river Danube. Galli et al. (1998) also confirmed that P. laevis was restricted to unpolluted and slightly polluted sites of four investigated rivers. Parasitic infections in fish depend on intermediate hosts, and $P$. laevis uses as its intermediate host a gammarid species, which are known to be sensitive to pollution (Galli et al., 2001; Kennedy 2006). Therefore, contrast between metal tolerance of acanthocephalans and their reduced appearance at metal contaminated sites could be explained by the sensitivity of their intermediate hosts to water pollution (Lafferty, 1997).

\section{Conclusions}

Although water quality of the Sutla River was defined as acceptable and indicated only moderate faecal, organic and trace element contamination, assessment of general condition of European chub (S. cephalus) inhabiting this river pointed to specific biological changes, which indicated increased stress due to unfavourable living conditions. At the sites with continuously decreased oxygen saturation, several changes were observed. Gonadosomatic and gill indices were increased, as a possible sign of some disturbance in reproductive cycle and increased demands for oxygen, respectively. Fish condition was inferior, as seen from decreased Fulton condition indices. Slight increases of MT levels in gills, and especially liver, were observed, as well as prominently increased gill $\mathrm{Zn}$ concentrations, which could not be associated with increased metal exposure, but rather to specific physiological changes. At the site additionally contaminated with metals and faecal bacteria, increased susceptibility of internal organs to bacterial bioconcentration was observed. Contrary, frequency and abundance of parasitic infections was the lowest at that site, which is a characteristic finding in metal contaminated waters. In a conclusion, even weak and moderate contamination could cause disturbances in fish health and condition, especially in the case of concurrent presence of several contaminants or physico-chemical changes in the river water.

\section{Acknowledgements}


Dragun, Zrinka; Filipović Marijić, Vlatka; Kapetanović, Damir; Valić, Damir; Vardić Smrzlić, Irena; Krasnići, Nesrete; Strižak, Željka; Kurtović, Božidar; Teskeredžić, Emin; Raspor, Biserka. Assessment of general condition of fish inhabiting a moderately contaminated aquatic environment. // Environmental science and pollution research. 20 (2013), 7; 4954-4968.

489 The financial support by the Ministry of Science, Education and Sport of the Republic of Croatia (projects No.

490 098-0982934-2721 and 098-0982934-2752) is acknowledged. This study was carried out as a part of the

491 Monitoring of freshwater fishery in 2009 - Group D - Fishing area Sava River - Sutla River, funded by Ministry

492 of Agriculture, Fisheries and Rural Development of the Republic of Croatia. The authors are especially thankful

493 to Dr. Nevenka Mikac for the opportunity to use HR ICP-MS and to Branko Španović for the help in the field

494 work.

495

496

497

498

499 
Dragun, Zrinka; Filipović Marijić, Vlatka; Kapetanović, Damir; Valić, Damir; Vardić Smrzlić, Irena; Krasnići, Nesrete; Strižak, Željka; Kurtović, Božidar; Teskeredžić, Emin; Raspor, Biserka. Assessment of general condition of fish inhabiting a moderately contaminated aquatic environment. // Environmental science and pollution research. 20 (2013), 7; 4954-4968.

\section{References}

Adams SM, Shepard KL, Greeley MS, Jimenez BD, Ryon MG, Shugart LR, McCarthy JF (1989) The use of bioindicators for assessing the effects of pollutant stress on fish. Mar Environ Res 28:459-464

Amiard J-C, Amiard-Triquet C, Barka S, Pellerin J, Rainbow PS (2006) Metallothioneins in aquatic invertebrates: their role in metal detoxification and their use as biomarkers. Aquat Toxicol 76:160-202

Andres S, Ribeyre F, Tourencq J-N, Boudou A (2000) Interspecific comparison of cadmium and zinc contamination in the organs of four fish species along a polymetallic pollution gradient (Lot River, France). Sci Total Environ 248:11-25

Baer KN, Thomas P (1990) Influence of capture stress, salinity and reproductive status on zinc associated with metallothionein-like proteins in the livers of three marine teleost species. Mar Environ Res 28:157-161

Barton BA, Taylor BR (1996) Oxygen requirements of fishes in northern Alberta rivers with a general review of the adverse effects of low dissolved oxygen. Water Qual Res J Can 31:361-409

Benedicto J, Martínez-Gómez C, Campillo J (2005) Induction of metallothioneins in Mullus barbatus as specific biomarker of metal contamination: a field study in the western Mediterranean. Cienc Mar 31(1B):265-274

Berg LS (1964) Freshwater fishes of the USSR and adjacent countries (translated from Russian), vol. 2, 4th edn. (Russian version published 1949). Academy of Sciences of the USSR, Jerusalem, pp 496

Bremner I (1987)Nutritional and physiological significance of metallothionein. Experientia - Suppl. 52:81-107

Burleson ML, Wilhelm DR, Smatresk NJ (2001) The influence of fish size on the avoidance of hypoxia and oxygen selection by largemouth bass. J Fish Biol 59:1336-1349

Cajaraville MP, Bebianno MJ, Blasco J, Porte C, Sarasquete C, Viarengo A (2000) The use of biomarkers to assess the impact of pollution in coastal environments of the Iberian Peninsula: a practical approach. Sci Total Environ 247:295-311

Chapman LJ, Galis F, Shinn J (2000) Phenotypic plasticity and the possible role of genetic assimilation: hypoxia-induced trade-offs in the morphological traits of an African cichlid. Ecol Lett 3:387-393

Chapman LJ, Albert J, Galis F (2008a). Developmental plasticity, genetic differentiation, and hypoxia-induced trade-offs in an African cichlid fish. Open Evol 2:75-88

Chapman LJ, Chapman CA, Kaufman L, Witte F, Balirwa J (2008b). Biodiversity conservation in African waters: lessons of the Lake Victoria region. Vehr Internat Verein Limnol 30:16-34

Chesney EJ, Baltz DM, Thomas RG (2000) Louisiana estuarine and coastal fisheries and habitats: Perspectives from a fish's eye view. Ecol Appl 10:350-366

De Smet H, Blust R (2001) Stress responses and changes in protein metabolism in carp Cyprinus carpio during cadmium exposure. Ecotox Environ Safe 48:255-262

Diaz RJ (2001) Overview of hypoxia around the world. J Environ Qual 30:275-281

Dragun Z, Raspor B, Podrug M (2007) The influence of the season and biotic factors on the cytosolic metal concentrations in the gills of the European chub (Leuciscus cephalus L.). Chemosphere 69:911-919

Dragun Z, Podrug M, Raspor B (2009a) The assessment of natural causes of metallothionein variability in the gills of European chub (Squalius cephalus L.). Comp Biochem Phys C 150:209-217

Dragun Z, Roje V, Mikac N, Raspor B (2009b) Preliminary assessment of total dissolved trace metal concentrations in Sava River water. Environ Monit Assess 159:99-110 
Dragun, Zrinka; Filipović Marijić, Vlatka; Kapetanović, Damir; Valić, Damir; Vardić Smrzlić, Irena; Krasnići, Nesrete; Strižak,

Željka; Kurtović, Božidar; Teskeredžić, Emin; Raspor, Biserka. Assessment of general condition of fish inhabiting a

moderately contaminated aquatic environment. // Environmental science and pollution research. 20 (2013), 7; 4954-4968.

Dragun Z, Kapetanović D, Raspor B, Teskeredžić E (2011) Water quality of medium size watercourse under baseflow conditions: the case study of river Sutla in Croatia. Ambio 40:391-407

Elliott JM (1976) The energetics of feeding, metabolism and growth of brown trout (Salmo trutta L.) in relation to body weight, water temperature and ration size. J Anim Ecol 45:923-948

Encina L, Granado-Lorencio C (1997) Seasonal variations in the physiological status and energy content of somatic and reproductive tissues of chub. J Fish Biol 50:511-522

Erk M, Ivanković D, Raspor B, Pavičić J (2002) Evaluation of different purification procedures for the electrochemical quantification of mussel metallothioneins. Talanta 57:1211-1218

Falchuk KH, Czupryn M (1991) Isolation of metallothioneins under metal-free conditions. In: Riordan JF, Vallee BL (eds) Methods in Enzymology, Volume 205, Metallobiochemistry Part B, Metallothionein and Related Molecules. Academic Press Inc., San Diego, pp 47-53

Fattal B, Dotan A, Parpari L, Techorsh Y, Cabelli VJ (1993) Microbiological purification of fish grown in fecally contaminated commercial fish pond. Water Sci Technol 27:303-311

Filipović Marijić V, Raspor B (2006) Age and tissue dependent metallothionein and cytosolic metal distribution in a native Mediterranean fish, Mullus barbatus, from the Eastern Adriatic Sea. Comp Biochem Phys C 143:382-387

Filipović Marijić V, Raspor B (2007) Metal exposure assessment in native fish, Mullus barbatus L., from the Eastern Adriatic Sea. Toxicol Lett 168:292-301

Filipović Marijić V, Raspor B (2008) Hepatic metallothionein and metal ( $\mathrm{Zn}, \mathrm{Cu}$ and $\mathrm{Cd}$ ) variability in relation to reproductive cycle of Mullus barbatus and Merluccius merluccius from the Eastern Adriatic Sea. Fresen Environ Bull 17:705-712

Filipović Marijić V, Raspor B (2010) The impact of fish spawning on metal and protein levels in gastrointestinal cytosol of indigenous European chub. Comp Biochem Phys C 152:133-138

Friesen CN, Aubin-Horth N, Chapman LJ (2012) The effect of hypoxia on sex hormones in an African cichlid Pseudocrenilabrus multicolorvictoriae. Comp Biochem Phys A 162:22-30

Galli RJ, Mariniello L, Crosa G, Ortis M, Mcchipinti Ambrogi A, D`Amelio S (1998) Populations of Acanthocephalus anguillae and Pomphorhynchus laevis in rivers with different pollution levels. J Helminthol 72:331-335

Galli P, Crosa G, Mariniello L, Ortis M, D'Amelio D (2001) Water quality as a determinant of the composition of fish parasite communities. Hydrobiologia 452:173-179

Gelnar M, Koubkova B, Plankova H, Jurajda P (1996) Report on metazoan parasites of fishes of the River Morava with remarks on the effects of water pollution. Helminthologia 31:47-56

Giguère A, Campbell PGC, Hare L, McDonald DG, Rasmussen JB (2004)Influence of lake chemistry and fish age on cadmium, copper, and zinc concentrations in various organs of indigenous yellow perch (Perca flavescens).Can J Fish Aquat Sci 61:1702-1716

Goldberg ED (1995) Emerging problems in the coastal zone for the twenty-first century. Mar Pollut Bull 31:152158

Graham JB (2006) Aquatic and aerial respiration.In: Evans DH, Claiborne JB (eds) The Physiology of Fishes. Taylor \& Francis, Boca Raton, pp 85-117 
Dragun, Zrinka; Filipović Marijić, Vlatka; Kapetanović, Damir; Valić, Damir; Vardić Smrzlić, Irena; Krasnići, Nesrete; Strižak, Željka; Kurtović, Božidar; Teskeredžić, Emin; Raspor, Biserka. Assessment of general condition of fish inhabiting a moderately contaminated aquatic environment. // Environmental science and pollution research. 20 (2013), 7; 4954-4968.

Hattink J, De Boeck G, Blust R (2005) The toxicokinetics of cadmium in carp under normoxic and hypoxic conditions. Aquat Toxicol 75:1-15

Hogstrand C, Lithner G, Haux C (1991) The importance of metallothionein for the accumulation of copper, zinc and cadmium in environmentally exposed perch, Perca fluviatilis. Pharmacol Toxicol 68:492-501

HRN EN 14011 (2005) Fish sampling by electric power

Hylland K, Nissen-Lie T, Christensen PG, Sandvik M (1998) Natural modulation of hepatic metallothionein and cytochrome P4501A in flounder, Platichthys flesus L. Mar Environ Res 46:51-55

Kägi JHR, Schäffer A (1988) Biochemistry of metallothionein. Biochemistry 27:8509-8515

Kapetanović D, Kurtović B, Teskeredžić E (2005) Differences in bacterial population in rainbow trout (Oncorhynchus mykiss Walbum) fry after transfer from incubator to pools. Food Technol Biotech 43:189193

Kennedy CR (2006) Ecology of the Acanthocephala. Cambridge University Press, Cambridge, UK

Khan RA, Barker DE, Ryan K, Murphy B, Hooper RG (1996) Abnormalities in winter flounder (Pleuronectes americanus) living near a paper mill in the Humber Arm, Newfoundland.In: Servos MR, Munkittrick KR, Carey JH, Van Der Kraak GJ (eds) Environmental Fate and Effects of Pulp and Paper Mill Effluents. St. Lucie Press, Del Ray Beach, pp 511-523

Kramer DL (1987) Dissolved oxygen and fish behavior. Environ Biol Fish 18:81-92

Lafferty KD (1997) Environmental parasitology: What can parasites tell us about human impacts on the environment? Parasitol Today 13:251-255

Landry CA, Steele SL, Manning S, Cheek AO (2007) Long term hypoxia suppresses reproductive capacity in the estuarine fish, Fundulus grandis. Comp Biochem Physiol A 148:317-323

Lowry OH, Rosebrough NJ, Farr AL, Randall RJ (1951) Protein measurement with the Folin phenol reagent. J Biol Chem 193:265-275

Maage A, Waagbo R, Olsson P-E, Julshamn K, Sandnes K (1990) Ascorbate-2-sulfate as a dietary vitamin C source for Atlantic salmon (Salmo salar): 2. Effects of dietary levels and immunization on the metabolism of trace elements. Fish Physiol Biochem 8:429-436

Mills CA, Eloranta A (1985) Reproductive strategies in the stone loach, Noemacheilus barbatulus. Oikos 44:341-349

Moravec F (2004) Class Acanthocephala Rudolphi, 1808.In: Metazoan parasites of salmonid fishes of Europe, 1st edn. Academia Praha, Nakladatelstvi Academie ved Ceske Republiky, pp 380-412

Movahedinia A, Abtahi B, Bahmani M (2012) Gill histopathological lesions of the sturgeons. Asian J Anim Vet Adv 7:710-717

Ognev SI, Fink N (1956) The biology of vertebrae (In Croatian). Grafički zavod Hrvatske, Zagreb

Olsson P-E, Haux C, Förlin L (1987) Variation in hepatic metallothionein, zinc and copper levels during an annual reproductive cycle in rainbow trout, Salmo gairdneri. Fish Physiol Biochem 3:39-47

Olsson P-E, Zafarullah M, Foster R, Hamor T, Gedamu L (1990) Developmental regulation of metallothionein mRNA, zinc and copper levels in rainbow trout, Salmo gairdneri. Eur J Biochem 193:229-235

Öztaş H (1989) A study on the reproduction biology of the chub (Leuciscus cephalus L. 1758) in the Müceldi Stream in East Anatolia. Turk J Vet Anim Sci 13:171-179 
Dragun, Zrinka; Filipović Marijić, Vlatka; Kapetanović, Damir; Valić, Damir; Vardić Smrzlić, Irena; Krasnići, Nesrete; Strižak, Željka; Kurtović, Božidar; Teskeredžić, Emin; Raspor, Biserka. Assessment of general condition of fish inhabiting a moderately contaminated aquatic environment. // Environmental science and pollution research. 20 (2013), 7; 4954-4968.

Pathak SP, Gopal K (2005) Occurrence of antibiotic and metal resistance in bacteria from organs of river fish. Environ Res 98:100-103

Pihl L, Baden SP, Diaz RJ (1991) Effects of periodic hypoxia on distribution of demersal fish and crustaceans. Mar Biol 108:349-360

Podrug M, Raspor B (2009) Seasonal variation of the metal (Zn, Fe, Mn) and metallothionein concentrations in the liver cytosol of the European chub (Squalius cephalus L.). Environ Monit Assess 157:1-10

Podrug M, Raspor B, Erk M, Dragun Z (2009) Protein and metal concentrations in two fractions of hepatic cytosol of the European chub (Squalius cephalus L.). Chemosphere 75:843-849

Pollock MS, Clarke LMJ, Dubé MG (2007) The effects of hypoxia on fishes: from ecological relevance to physiological effects. Environ Rev 15:1-14

Pulliainen E, Korhonen K (1990) Seasonal changes in condition indices in adult mature and non-maturing burbot, Lota lota (L.), in the north-eastern Bothnian Bay, northern Finland. J Fish Biol 36:251-259

Randall DJ (1970) Gas exchange in fish.In: Hoar WS, Randall DJ (eds) Fish Physiology. Academic Press, London, pp 253-292

Randall D (1982) The control of respiration and circulation in fish during exercise and hypoxia. J Exp Biol 100:275-288

Randall D, Daxboeck C (1984) Oxygen and carbon dioxide transfer across fish gills. Fish Physiol 10:263-314

Raspor B, Paić M, Erk M (2001) Analysis of metallothioneins by the modified Brdička procedure. Talanta 55:109-115

Rätz H-J, Lloret J (2003) Variation in fish condition between Atlantic cod (Gadus morhua) stocks, the effect on their productivity and management implications. Fish Res 60:369-380

Rotchell JM, Clark KR, Newton LC, Bird DJ (2001) Hepatic metallothionein as a biomarker for metal contamination: age effects and seasonal variation in European flounders (Pleuronectes flessus) from the Severn Estuary and Bristol Channel. Mar Environ Res 52:151-171

Şaşi H (2004) The reproduction biology of chub (Leuciscus cephalus L. 1758) in Topçam Dam Lake (Aydın, Turkey). Turk J Vet Anim Sci 28:693-699

Sepúlveda MS, Gallagher EP, Gross TS (2004) Physiological changes in largemouth bass exposed to paper mill effluents under laboratory and field conditions. Ecotoxicology 13:291-301

Sepúlveda MS, Johnson WE, Higman JC, Denslow ND, Schoeb TR, Gross TS (2002) An evaluation of biomarkers of reproductive function and potential contaminant effects in Florida largemouth bass (Micropterus salmoides floridanus) sampled from the St. Johns River. Sci Total Environ 289:133-144

Shang EHH (2006) Hypoxia affects sex differentiation and development, leading to a male-dominated population in zebrafish (Danio rerio). Environ Sci Technol 40:3118-3122

Soimasuo MR, Aaltonen T, Nikinmaa M, Pellinen J, Ristola T, Oikari A (1995) Physiological toxicity of lowchlorine bleached pulp and paper mill effluent on whitefish (Coregonus lavaretus L. s.1): a laboratory exposure simulating lake pollution. Ecotox Safe 31:228-237

Sures B, Siddall R, Taraschewski H (1999) Parasites as accumulation indicators of heavy metal pollution. Parasitol Today 15:16-21

Teskeredžić E, Teskeredžić Z, Tomec M, Kurtović B, Raspor B, Kapetanović D, Dragun Z, Vardić I, Valić D, Strižak Ž, Španović B, Šoštarić Vulić Z, Roman Z (2009) Programme for the monitoring of the freshwater 
Dragun, Zrinka; Filipović Marijić, Vlatka; Kapetanović, Damir; Valić, Damir; Vardić Smrzlić, Irena; Krasnići, Nesrete; Strižak, Željka; Kurtović, Božidar; Teskeredžić, Emin; Raspor, Biserka. Assessment of general condition of fish inhabiting a moderately contaminated aquatic environment. // Environmental science and pollution research. 20 (2013), 7; 4954-4968. fishery status in the year 2009 -Group D - Fishing area Sava; River Sutla. [In Croatian: Program praćenja stanja slatkovodnog ribarstva u 2009. godini - Grupa D - ribolovno područje Sava; rijeka Sutla]. Ruđer Bošković Institute, Zagreb

Timmerman CM, Chapman LJ (2004) Hypoxia and interdemic variation in Poecilia latipinna. J Fish Biol 65:635-650

Treer T, Safner R, Aničić I, Lovrinov M (1995) Fishery (In Croatian). Globus, Zagreb

Ünver B (1998) An investigation on the reproduction properties of chub (Leuciscus cephalus L., 1758) in Lake Tödürge (Zara/Sivas). Turk J Zool 22:141-147

van Cleef KA, Kaplan LAE, Crivello JF (2000) The relationship between reproductive status and metallothionein mRNA expression in the common killifish, Fundulus heteroclitus. Environ Biol Fishes 57:97-105

van Dyk JC, Cochrane MJ, Wagenaar GM (2012) Liver histopathology of the sharptooth catfish Clarias gariepinus as a biomarker of aquatic pollution. Chemosphere 87:301-311

Vašák M (2005) Advances in metallothionein structure and functions. J Trace Elem Med Biol 19:13-17

Viarengo A, Burlando B, Dondero F, Marro A, Fabbri R (1999) Metallothionein as a tool in biomonitoring programmes. Biomarkers 4:455-466

Weltzien F, Doving KB, Carr WES (1999) Avoidance reaction of yolk-sac larvae of the inland silverside Menidia beryllina (Atherinidae) to hypoxia. J Exp Biol 202:2869-2876

Woo NYS, Wu RSS (1984) Changes in biochemical composition in the red grouper, Epinephelus akaara (Temminck and Schlegel), and the Black Sea bream, Mylio macrocephalus (Basilewsky), during hypoxic exposure. Comp Biochem Physiol A Physiol 77:475-482

Zorita I, Ortiz-Zarragoitia M, Apraiz I, Cancio I, Orbea A, Soto M, Marigómez I, Cajaraville MP (2008) Assessment of biological effects of environmental pollution along the NW Mediterranean Sea using red mullets as sentinel organisms. Environ Pollut 153:157-168 
Dragun, Zrinka; Filipović Marijić, Vlatka; Kapetanović, Damir; Valić, Damir; Vardić Smrzlić, Irena; Krasnići, Nesrete; Strižak, Željka; Kurtović, Božidar; Teskeredžić, Emin; Raspor, Biserka. Assessment of general condition of fish inhabiting a moderately contaminated aquatic environment. // Environmental science and pollution research. 20 (2013), 7; 4954-4968.

Figure captions

Figure 1. The map of the Sutla River with marked sampling sites (1-5).

Figure 2. Biometric parameters of European chub caught in the Sutla River at five sampling sites: a) percentage of females (presented as bars); b) chub age (presented as error bars, i.e. mean and standard deviation); c) chub total body mass (presented as box plots). The boundaries of boxplot indicate $25^{\text {th }}$ and $75^{\text {th }}$ percentiles; a line within the box marks the median value; whiskers above and below the box indicate $10^{\text {th }}$ and $90^{\text {th }}$ percentiles, whereas dots indicate outliers. Differences among sites are indicated with different letters (a, b) (Kruskal-Wallis One Way Analysis of Variance on Ranks, post hoc Dunn's test). Number of samples per each site was 15, except for age at the site $1(n=14)$.

Figure 3. Biometric parameters of European chub caught in the Sutla River at five sampling sites: a) Fulton condition index (FCI); b) gonadosomatic index of both females and males (GSI); c) organosomatic index for gills; d) hepatosomatic index (HSI). The results are presented as box plots and compared, as described in the caption of Figure 2. Number of samples per each site was 15, except for HSI at the site 2 ( $n=14)$.

Figure 4. The concentrations of metallothioneins (MT) and total cytosolic proteins (TP) in two organs of European chub caught in the Sutla River at five sampling sites: a) MT in liver; b) MT in gills; c) TP in liver; d) TP in gills. The results are presented as box plots and compared, as described in the caption of Figure 2. Number of samples per each site was 15 , except for MT and TP in liver at the site $1(n=14)$.

Figure 5. The cytosolic concentrations of three metals in two organs of European chub caught in the Sutla River at five sampling sites: a) $\mathrm{Zn}$ in liver; b) $\mathrm{Zn}$ in gills; c) $\mathrm{Cu}$ in liver; d) $\mathrm{Cu}$ in gills; e) $\mathrm{Cd}$ in liver; f) $\mathrm{Cd}$ in gills. The results are presented as box plots and compared, as described in the caption of Figure 2. Number of samples per each site was 15, except for $\mathrm{Zn}, \mathrm{Cu}$ and $\mathrm{Cd}$ in liver at the sites 1, 3 and 5 ( $\mathrm{n}=14)$, and $\mathrm{Zn}, \mathrm{Cu}$ and $\mathrm{Cd}$ in gills at the site $3(n=14)$.

Figure 6. Bacterial bioconcentration in European chub caught in the Sutla River at five sampling sites expressed as frequency in a) gills; b) liver; c) spleen; d) kidney, and intensity in e) gills; f) liver; g) spleen; h) kidney. The results for frequency are presented as bars, whereas the results for intensity are presented as box plots and compared, as described in the caption of Figure 2. Number of samples per each site was 5, except for the site 1 $(n=6)$.

Figure 7. Data on a) frequency and b) abundance of infections with Pomphorhynchus laevis in the intestine of European chub caught in the Sutla River at five sampling sites. The results for frequency are presented as bars, whereas the results for abundance are presented as box plots and compared, as described in the caption of Figure 2. Number of samples per each site was 15 . 


\section{Figure 1.}

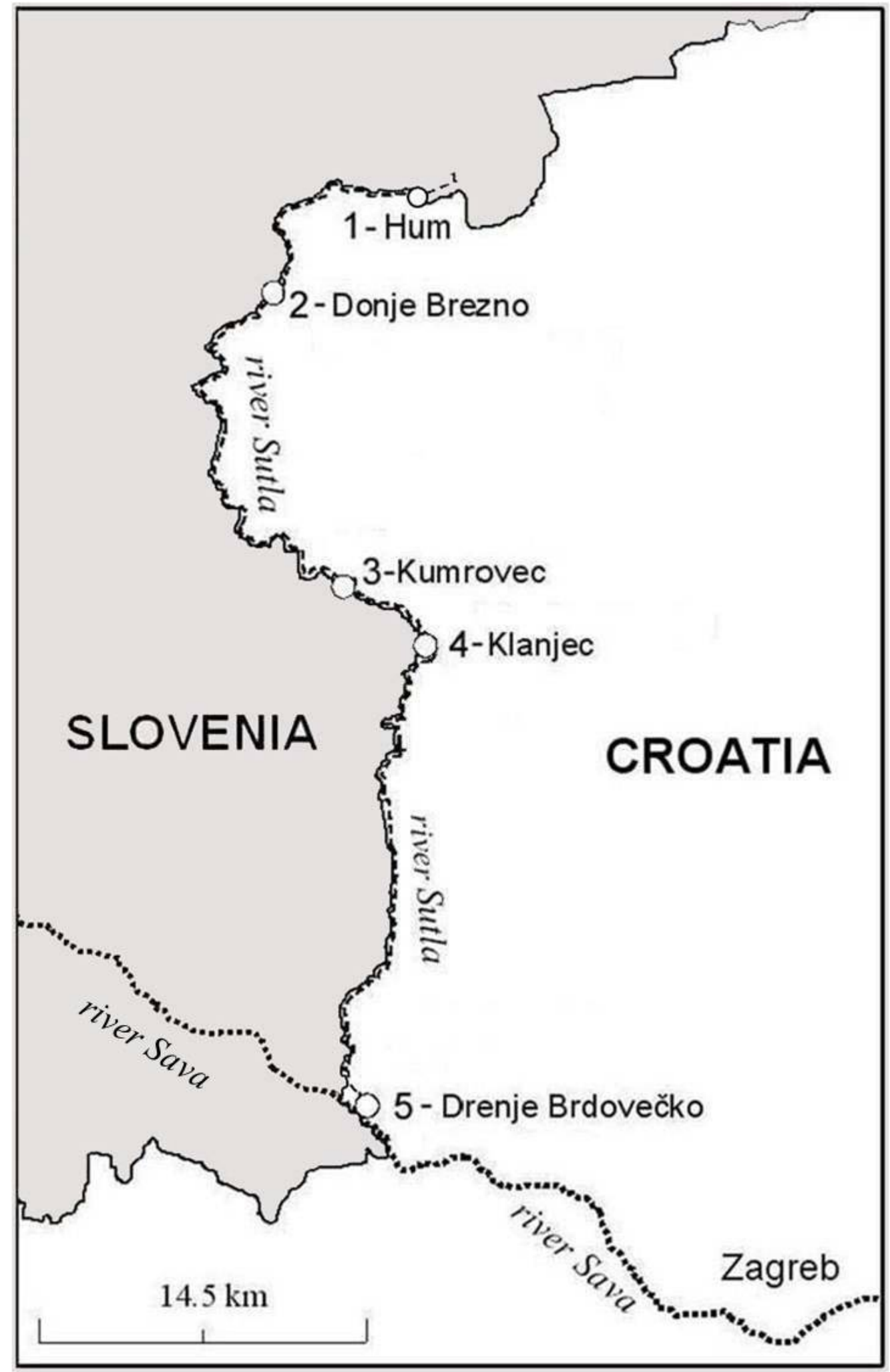


Dragun, Zrinka; Filipović Marijić, Vlatka; Kapetanović, Damir; Valić, Damir; Vardić Smrzlić, Irena; Krasnići, Nesrete; Strižak, Željka; Kurtović, Božidar; Teskeredžić, Emin; Raspor, Biserka. Assessment of general condition of fish inhabiting a moderately contaminated aquatic environment. // Environmental science and pollution research. 20 (2013), 7; 4954-4968.

\section{Figure 2.}
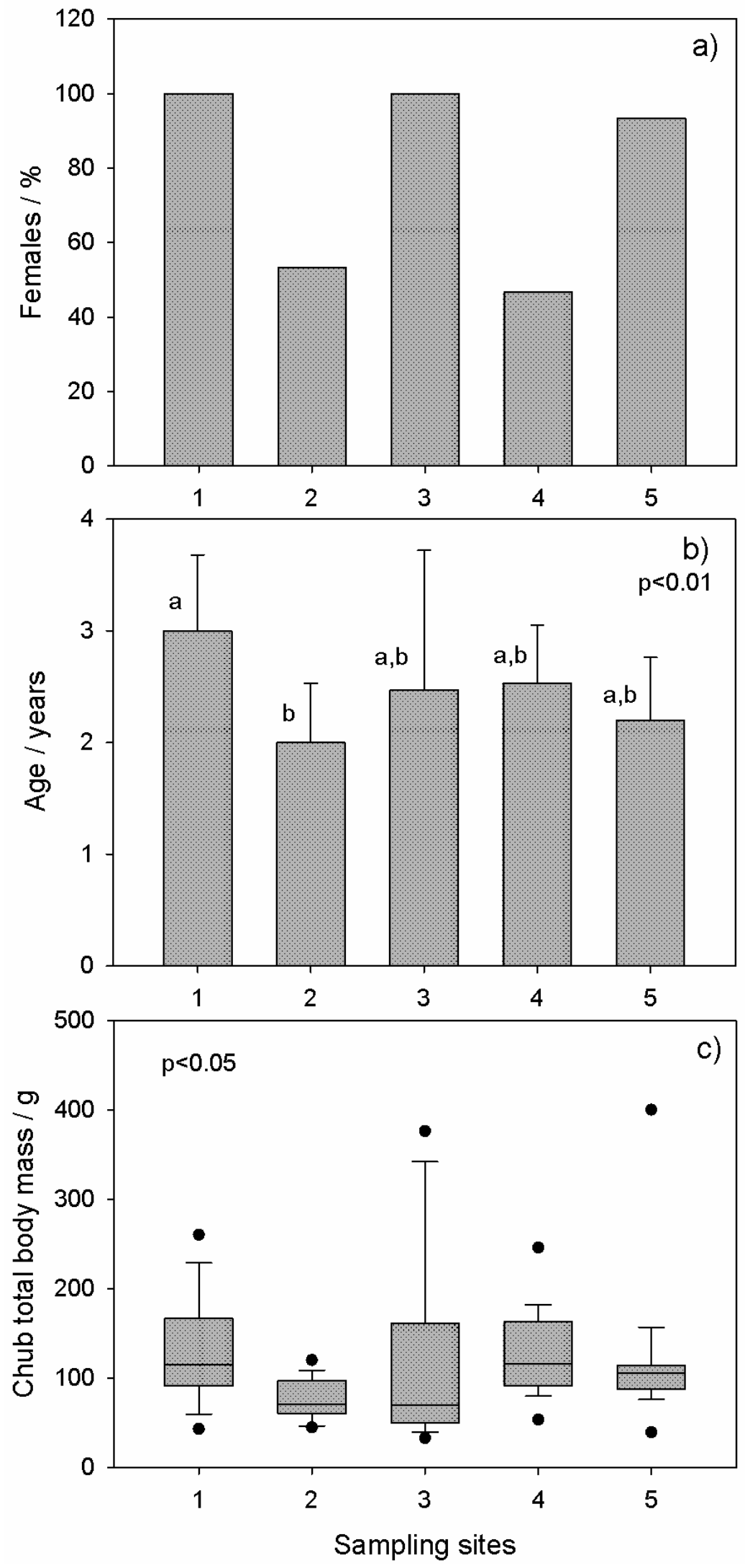
Dragun, Zrinka; Filipović Marijić, Vlatka; Kapetanović, Damir; Valić, Damir; Vardić Smrzlić, Irena; Krasnići, Nesrete; Strižak, Željka; Kurtović, Božidar; Teskeredžić, Emin; Raspor, Biserka. Assessment of general condition of fish inhabiting a moderately contaminated aquatic environment. // Environmental science and pollution research. 20 (2013), 7; 4954-4968.

\section{Figure 3.}
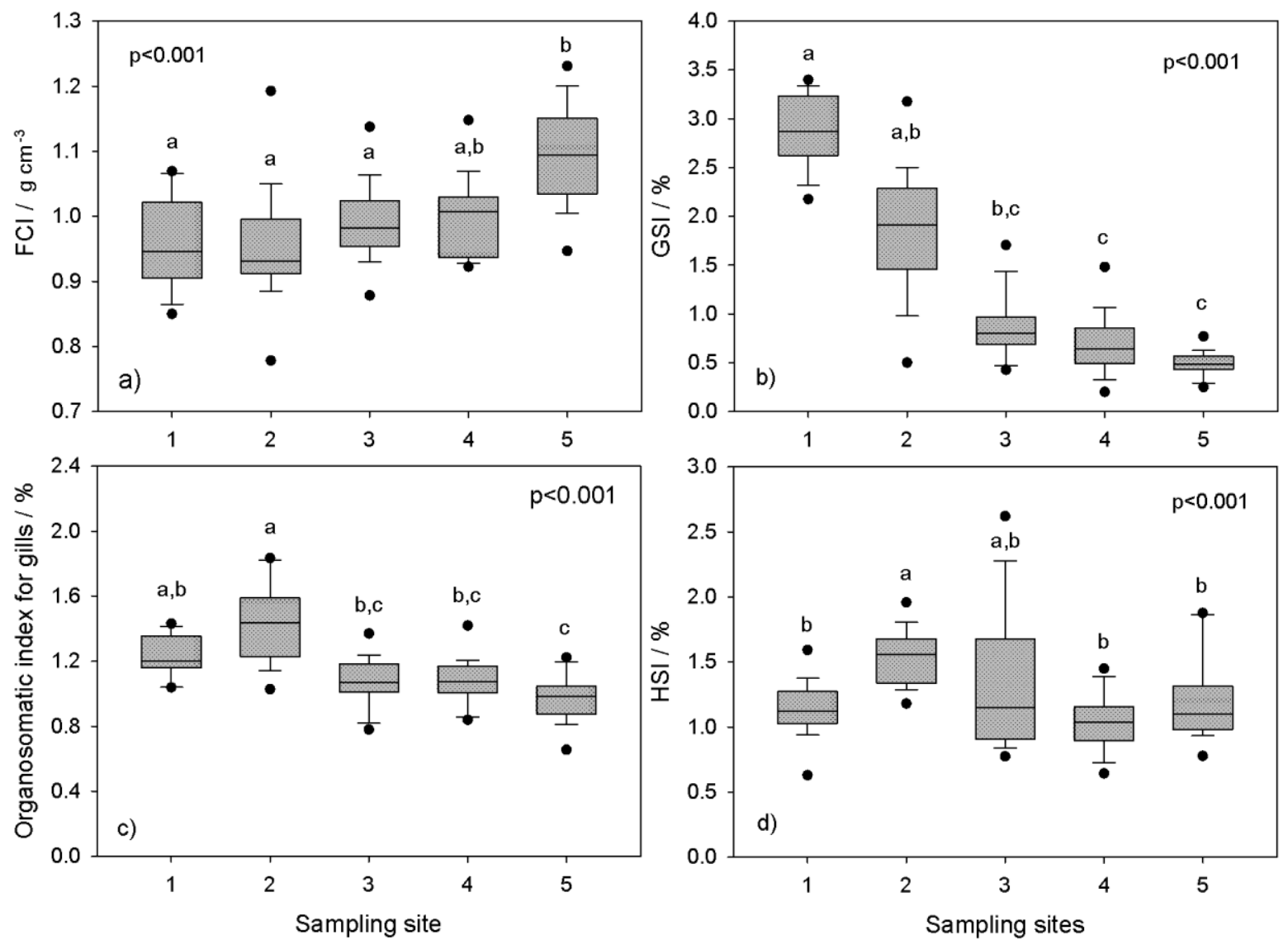
Dragun, Zrinka; Filipović Marijić, Vlatka; Kapetanović, Damir; Valić, Damir; Vardić Smrzlić, Irena; Krasnići, Nesrete; Strižak, Željka; Kurtović, Božidar; Teskeredžić, Emin; Raspor, Biserka. Assessment of general condition of fish inhabiting a moderately contaminated aquatic environment. // Environmental science and pollution research. 20 (2013), 7; 4954-4968.

\section{Figure 4.}
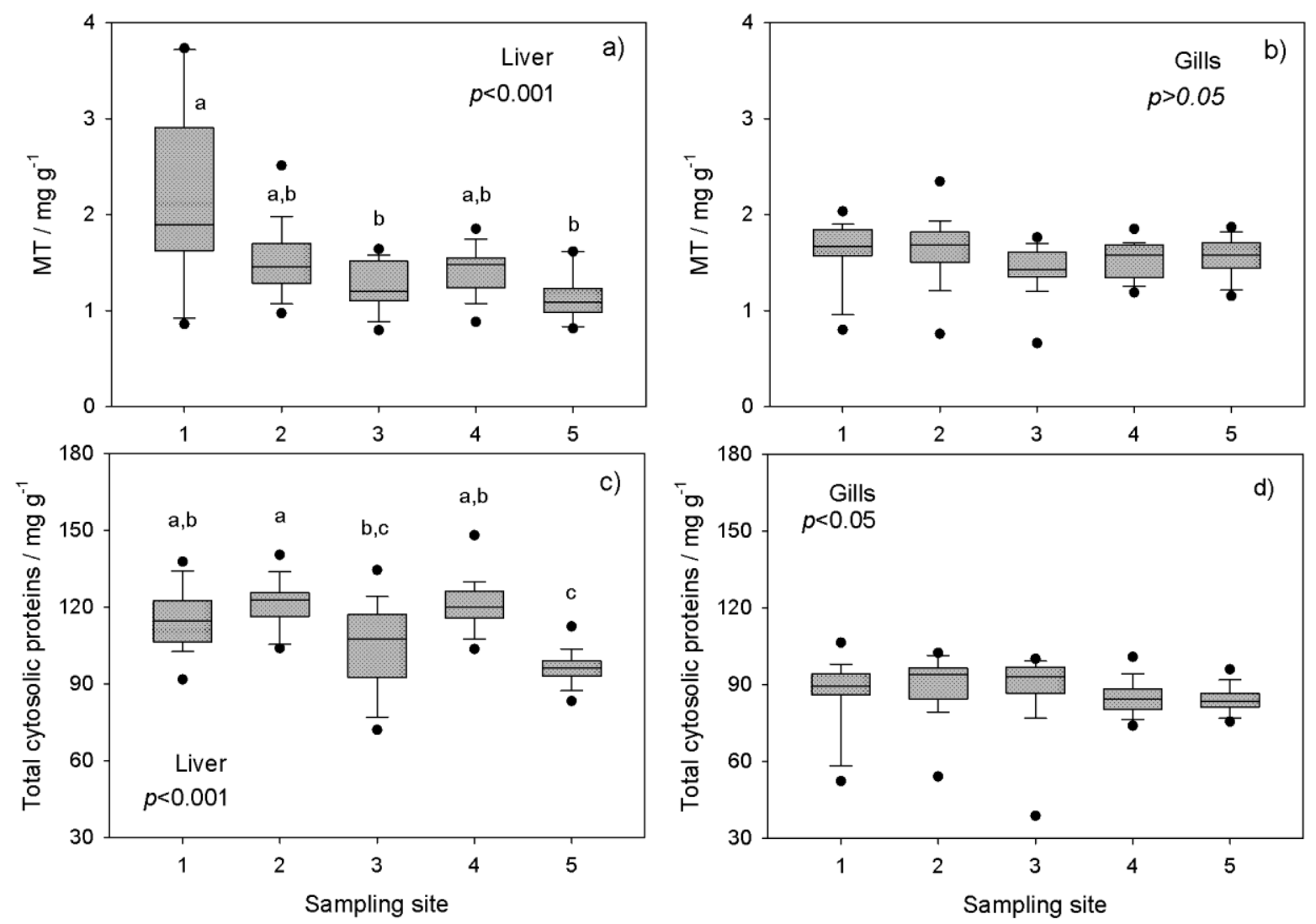
Dragun, Zrinka; Filipović Marijić, Vlatka; Kapetanović, Damir; Valić, Damir; Vardić Smrzlić, Irena; Krasnići, Nesrete; Strižak, Željka; Kurtović, Božidar; Teskeredžić, Emin; Raspor, Biserka. Assessment of general condition of fish inhabiting a moderately contaminated aquatic environment. // Environmental science and pollution research. 20 (2013), 7; 4954-4968.

\section{Figure 5.}
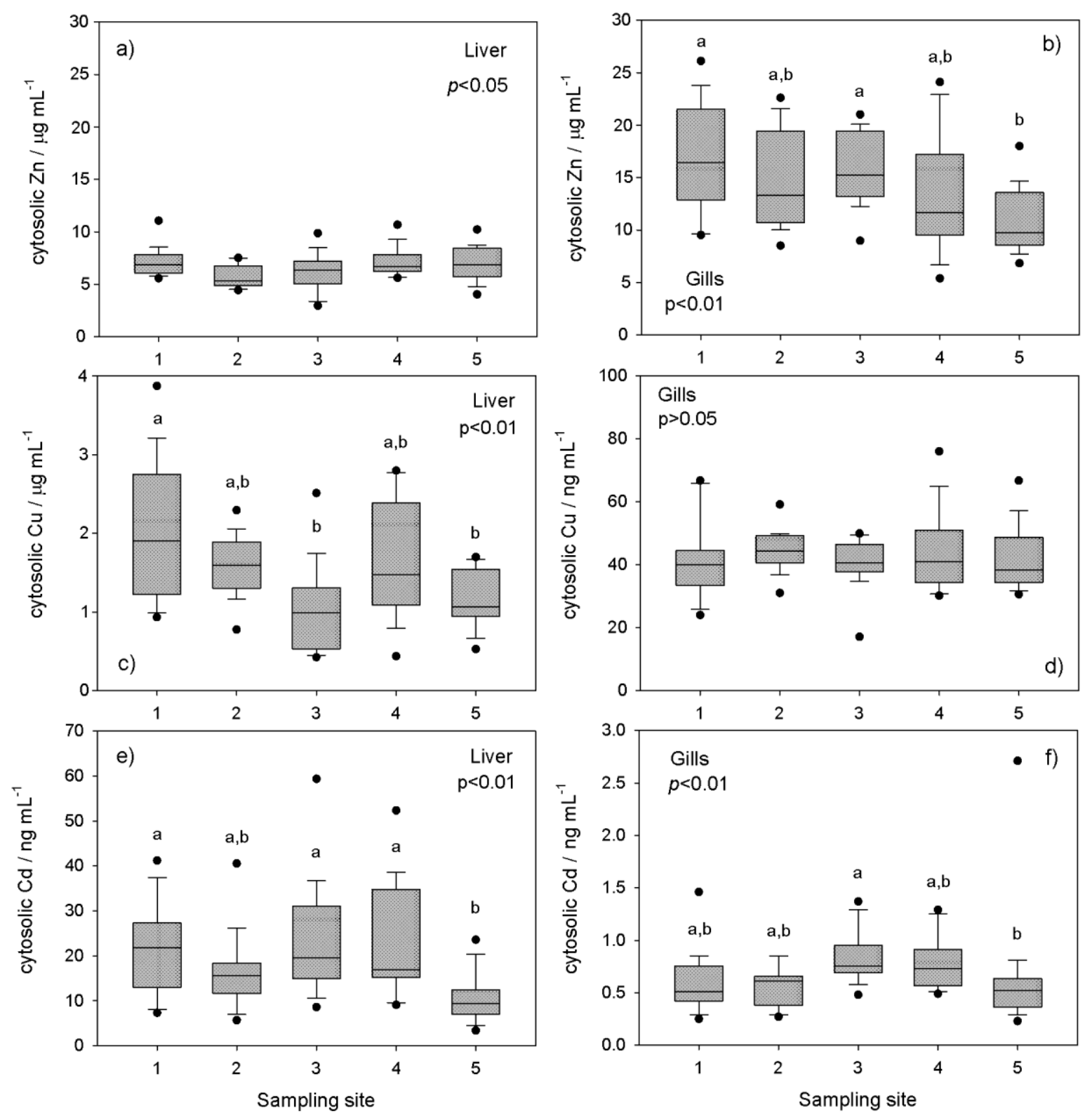
Dragun, Zrinka; Filipović Marijić, Vlatka; Kapetanović, Damir; Valić, Damir; Vardić Smrzlić, Irena; Krasnići, Nesrete; Strižak, Željka; Kurtović, Božidar; Teskeredžić, Emin; Raspor, Biserka. Assessment of general condition of fish inhabiting a moderately contaminated aquatic environment. // Environmental science and pollution research. 20 (2013), 7; $4954-4968$.

\section{Figure 6.}
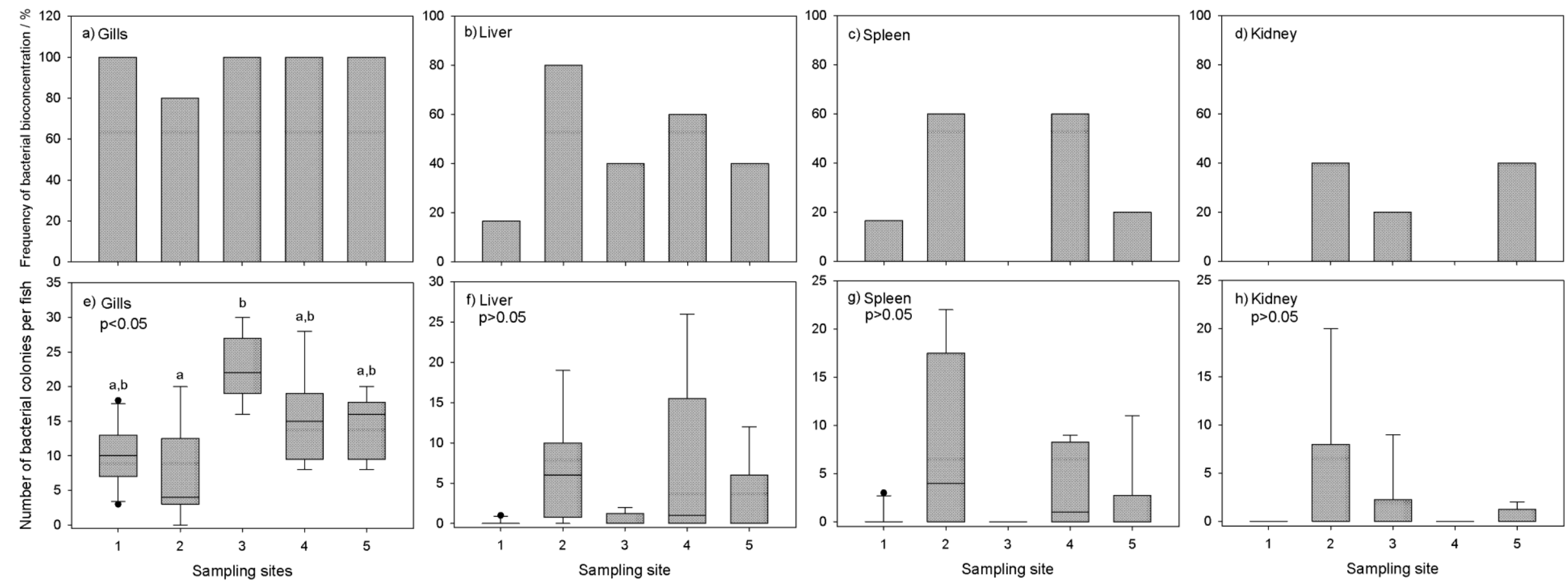
Dragun, Zrinka; Filipović Marijić, Vlatka; Kapetanović, Damir; Valić, Damir; Vardić Smrzlić, Irena; Krasnići, Nesrete; Strižak, Željka; Kurtović, Božidar; Teskeredžić, Emin; Raspor, Biserka. Assessment of general condition of fish inhabiting a moderately contaminated aquatic environment. // Environmental science and pollution research. 20 (2013), 7; 4954-4968.

Figure 7.
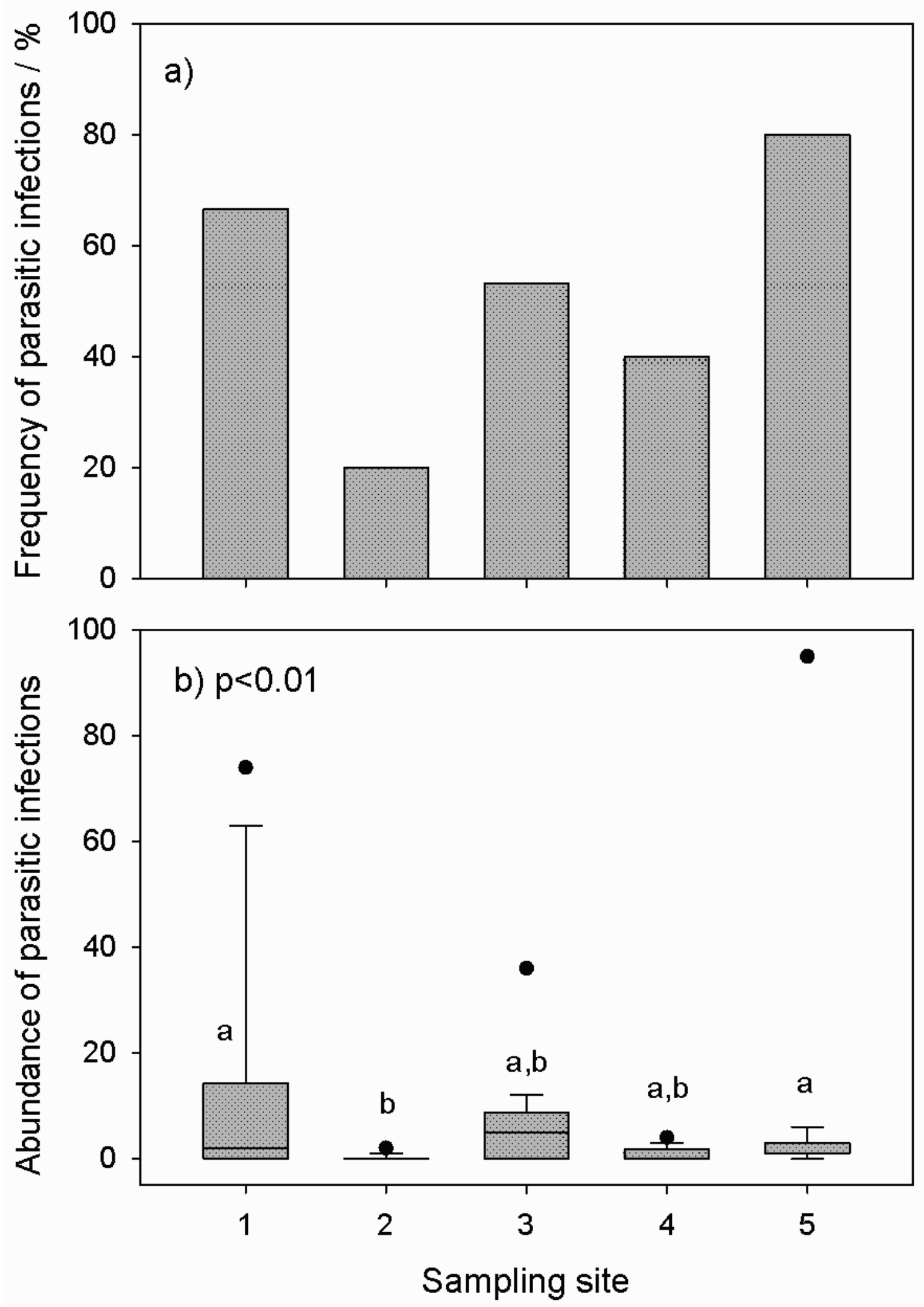
Dragun, Zrinka; Filipović Marijić, Vlatka; Kapetanović, Damir; Valić, Damir; Vardić Smrzlić, Irena; Krasnići, Nesrete; Strižak, Željka; Kurtović, Božidar; Teskeredžić, Emin; Raspor, Biserka. Assessment of general condition of fish inhabiting a moderately contaminated aquatic environment. // Environmental science and pollution research. 20 (2013), 7; 4954-4968.

Table 1. The selected parameters indicating Sutla River water quality in September of 2009, at five sampling sites (1 - Hum na Sutli; 2 - Donje Brezno; 3 - Kumrovec; 4 - Klanjec; 5 - Drenje Brdovečko; Dragun et al. 2011).

\begin{tabular}{|c|c|c|c|c|c|c|c|}
\hline & $\begin{array}{c}\text { Conductivi } \\
\text { ty } \\
/ \boldsymbol{\mu S} \mathbf{c m}^{-1}\end{array}$ & $\begin{array}{c}\text { Dissolve } \\
\text { d } \\
\text { oxygen / } \\
\%(\mathbf{m g} \\
\left.\mathbf{L}^{-1}\right) \\
\end{array}$ & $\begin{array}{c}\text { Heterotroph } \\
\text { ic bacteria } \\
/ \text { cfu } \mathbf{~ m L}^{-1}\end{array}$ & $\begin{array}{c}\text { Total } \\
\text { coliforms } \\
/ \\
\text { MPN/100 } \\
\text { mL } \\
\end{array}$ & $\begin{array}{c}\text { Na } \\
/ \mu \mathbf{g} \mathbf{L}^{-1}\end{array}$ & $\underset{/ \mu g \mathbf{L}^{-1}}{\mathbf{K}}$ & $\begin{array}{c}\text { Trace } \\
\text { element } \\
\text { s }\end{array}$ \\
\hline 1 & 526.0 & $\begin{array}{c}51.2 \\
(4.57)\end{array}$ & $20000 \pm 5657$ & $7814 \pm 542$ & $\begin{array}{c}14204 \pm 38 \\
6\end{array}$ & $\begin{array}{c}3839 \pm 15 \\
7\end{array}$ & low \\
\hline 2 & 976.0 & $\begin{array}{c}53.7 \\
(5.06)\end{array}$ & $24000 \pm 1414$ & $\begin{array}{c}15739 \pm 31 \\
04\end{array}$ & $\begin{array}{c}89435 \pm 66 \\
1\end{array}$ & $\begin{array}{c}10783 \pm 3 \\
30\end{array}$ & $\begin{array}{c}\text { increase } \\
\mathrm{d}\end{array}$ \\
\hline 3 & 569.5 & $\begin{array}{c}94.1 \\
(9.01)\end{array}$ & $5500 \pm 990$ & $3075 \pm 272$ & $\begin{array}{c}14585 \pm 37 \\
1\end{array}$ & $\begin{array}{c}3842 \pm 10 \\
3\end{array}$ & low \\
\hline 4 & 560.0 & $\begin{array}{c}91.7 \\
(8.85)\end{array}$ & $4650 \pm 71$ & $5631 \pm 598$ & $\begin{array}{c}11699 \pm 12 \\
3\end{array}$ & $\begin{array}{c}3446 \pm 15 \\
1\end{array}$ & low \\
\hline 5 & 559.5 & $\begin{array}{c}86.6 \\
(7.06) \\
\end{array}$ & $7000 \pm 2828$ & $2305 \pm 447$ & $\begin{array}{c}11763 \pm 28 \\
.6 \\
\end{array}$ & $\begin{array}{c}3742 \pm 10 \\
7\end{array}$ & low \\
\hline
\end{tabular}


Dragun, Zrinka; Filipović Marijić, Vlatka; Kapetanović, Damir; Valić, Damir; Vardić Smrzlić, Irena; Krasnići, Nesrete; Strižak, Željka; Kurtović, Božidar; Teskeredžić, Emin; Raspor, Biserka. Assessment of general condition of fish inhabiting a moderately contaminated aquatic environment. // Environmental science and pollution research. 20 (2013), 7; 4954-4968.

Table 2. The comparison of several parameters (medians) determined for European chub caught at upstream and downstream sections of the Sutla River (upstream sampling area: Hum na Sutli and Donje Brezno; downstream sampling area: Kumrovec, Klanjec and Drenje Brdovečko): FCI (Fulton condition index), GSI (gonadosomatic index of both females and males), gill index, MTL/MT-G (metallothionein concentraton in liver/gills), TP-L/TP-G (total cytosolic protein concentration in liver/gills), $\mathrm{Cu}-\mathrm{L} / \mathrm{Zn}-\mathrm{G}$ (cytosolic metal concentration in liver/gills).

\begin{tabular}{|c|c|c|c|c|c|c|c|c|c|c|}
\hline & ${ }^{a} n$ & $\begin{array}{l}\text { FCI / } \\
\mathrm{g} \mathrm{cm}^{-3}\end{array}$ & $\begin{array}{c}\text { GSI / } \\
\%\end{array}$ & $\begin{array}{c}\text { Gill } \\
\text { index } \\
/ \%\end{array}$ & $\begin{array}{l}\text { MT-L } \\
/ / \\
\text { mg g }^{-1}\end{array}$ & $\begin{array}{c}\text { MT- } \\
\text { G / } \\
\text { mg } \\
\text { g }^{-1}\end{array}$ & $\begin{array}{l}\text { TP- } \\
\text { L / } \\
\text { mg } \\
\mathbf{g}^{-1}\end{array}$ & $\begin{array}{l}\text { TP- } \\
\text { G / } \\
\text { mg } \\
\mathbf{g}^{-1}\end{array}$ & $\begin{array}{c}\mathrm{Cu}- \\
\mathbf{L} / \\
\mu \mathrm{g} \\
\mathbf{m L}^{-1}\end{array}$ & $\begin{array}{c}\text { Zn- } \\
\text { G / } \\
\mu \mathrm{g} \\
\text { mL }^{-1}\end{array}$ \\
\hline $\begin{array}{c}\text { Upstream } \\
\text { sampling } \\
\text { area }\end{array}$ & $\begin{array}{l}3 \\
0\end{array}$ & 0.939 & 2.39 & 1.30 & 1.625 & $\begin{array}{c}1.67 \\
4\end{array}$ & $\begin{array}{c}117 . \\
0\end{array}$ & 92.0 & 1.67 & $\begin{array}{c}14.8 \\
2\end{array}$ \\
\hline $\begin{array}{c}\text { Downstrea } \\
\text { m sampling } \\
\text { area }\end{array}$ & $\begin{array}{l}4 \\
5\end{array}$ & 1.018 & 0.61 & 1.04 & 1.231 & $\begin{array}{c}1.55 \\
5\end{array}$ & $\begin{array}{c}107 . \\
5\end{array}$ & 85.8 & 1.11 & $\begin{array}{c}12.9 \\
5\end{array}$ \\
\hline${ }^{\mathbf{b}} p$ & & $\begin{array}{c}<0.00 \\
1\end{array}$ & $\begin{array}{c}<0.00 \\
1\end{array}$ & $\begin{array}{c}<0.00 \\
1\end{array}$ & $\begin{array}{c}<0.00 \\
1\end{array}$ & $\begin{array}{c}<0.0 \\
5\end{array}$ & $\begin{array}{c}<0.0 \\
1\end{array}$ & $\begin{array}{c}>0.0 \\
5\end{array}$ & $\begin{array}{c}<0.0 \\
1\end{array}$ & $\begin{array}{c}<0.0 \\
5\end{array}$ \\
\hline
\end{tabular}

a - number of samples (except for MT-L, TP-L and Cu-L at upstream sampling area, $n=29$; and $\mathrm{Cu}-\mathrm{L}$ and $\mathrm{Zn}-\mathrm{G}$ at downstream sampling area, $\mathrm{n}=43$ and 44 , respectively)

$\mathrm{b}$ - the level of significance ( $p$ ) for observed differences (Mann-Whitney Rank Sum Test) 
Table 3. Spatial variability of three biometric parameters (medians): Fulton condition index (FCI) distinguished by chub sex, and gonadosomatic index (GSI) and hepatosomatic index (HSI) distinguished by chub age.

\begin{tabular}{|c|c|c|c|c|c|c|}
\hline & \multicolumn{2}{|c|}{ FCI $/ \mathrm{g} \mathrm{cm}^{-3}$} & \multicolumn{2}{|c|}{ GSI / \% } & \multicolumn{2}{|c|}{ HSI / \% } \\
\hline & Females & Males & 1-2year & 3-4year & 1-2year & 3-4year \\
\hline Site 1 & a 0.946 & - & a2.66 & a2.89 & $\mathrm{a}, \mathrm{b} 1.31$ & 1.12 \\
\hline Site 2 & ${ }^{\mathrm{a}} 0.967$ & ${ }^{\mathrm{a}} 0.921$ & ${ }^{\mathrm{a}} 1.52$ & a,b 2.27 & ${ }^{\mathrm{a}} 1.56$ & 1.57 \\
\hline Site 3 & ${ }^{\mathrm{a}} 0.982$ & - & ${ }^{a, b} 0.71$ & ${ }^{\mathrm{a}, \mathrm{b}} 0.98$ & $\mathrm{a}, \mathrm{b} 1.49$ & 1.00 \\
\hline Site 4 & ${ }^{\mathrm{a}, \mathrm{b}} 1.018$ & b 0.961 & ${ }^{\mathrm{b}} 0.58$ & ${ }^{\mathrm{b}} 0.75$ & ${ }^{\mathrm{b}} 1.05$ & 1.00 \\
\hline Site 5 & b 1.095 & - & b 0.47 & ${ }^{\mathrm{b}} 0.58$ & $\mathrm{a}, \mathrm{b} 1.12$ & 1.10 \\
\hline
\end{tabular}

${ }^{a, b}$ different letters indicate statistically significant differences between sites $(p<0.05)$ (Kruskal-Wallis One Way Analysis of Variance on Ranks with post-hoc Dunn's test or Mann-Whitney Rank Sum Test) 
Dragun, Zrinka; Filipović Marijić, Vlatka; Kapetanović, Damir; Valić, Damir; Vardić Smrzlić, Irena; Krasnići, Nesrete; Strižak, Željka; Kurtović, Božidar; Teskeredžić, Emin; Raspor, Biserka. Assessment of general condition of fish inhabiting a moderately contaminated aquatic environment. // Environmental science and pollution research. 20 (2013), 7; 4954-4968.

Table 4. Multiple regression model for MTs ( $\mathrm{mg} \mathrm{g}^{-1}$, wet mass) as dependent variable for chub liver $\left(\mathrm{n}=75 ; \mathrm{R}=0.611\right.$; adjusted $\left.\mathrm{R}^{2}=0.347 ; p<0.001\right)$ and for chub gills $(\mathrm{n}=75$; $\mathrm{R}=0.735$; adjusted $\mathrm{R}^{2}=0.520 ; p<0.001$ ); analysis was performed on standardized values using Forward Stepwise Regression, with the following independent variables: total chub mass (g), hepatosomatic index (HSI, \%), gill organosomatic index (\%), Fulton condition index (FCI, $\mathrm{g} \mathrm{cm}^{-3}$ ), gonadosomatic index (GSI, \%), total cytosolic proteins in liver/gills (TP-L/TP-G), cytosolic Zn in liver/gills ( $\mathrm{Zn}-\mathrm{L} / \mathrm{Zn}-\mathrm{G})$, cytosolic $\mathrm{Cu}$ in liver/gills (Cu$\mathrm{L} / \mathrm{Cu}-\mathrm{G})$ and cytosolic $\mathrm{Cd}$ in liver/gills (Cd-L/Cd-G). Coefficients are presented for the independent variables that exhibited the strongest association with MT level.

\begin{tabular}{|lrrrrrrr|}
\hline & \multicolumn{2}{c}{ Liver } & & & \multicolumn{3}{c|}{ Gills } \\
\cline { 1 - 2 } $\begin{array}{l}\text { Independent } \\
\text { variables }\end{array}$ & Coefficients & $\boldsymbol{p}$ & & $\begin{array}{l}\text { Independent } \\
\text { variables }\end{array}$ & Coefficients & $\boldsymbol{p}$ \\
${$\cline { 1 - 2 }$} }$ & 0.330 & $<0.01$ & & TP-G & 0.533 & $<0.001$ \\
Cu-L & 0.267 & $<0.05$ & & Gill index & 0.200 & $<0.05$ \\
TP-L & 0.193 & $<0.05$ & & Zn-G & 0.194 & $<0.05$ \\
\hline
\end{tabular}

